\title{
Effect of Foliar Spraying Faba Bean Plants with Some Botanical Extracts and Salicylic Acid on Growth, Yield and Chocolate Spot Disease Severity
}

\author{
Amina I. El-Shafey ${ }^{1}$, A. M. El-Garhy ${ }^{2}$ and M. M. H. Rahhal ${ }^{3}$ \\ ${ }^{1}$ Crop Physiol. Res. Dept., Field Crops Res. Inst., Agric. Res. Cent., Giza, Egypt. \\ ${ }^{2}$ Food Legume Res. Dept., Field Crops Res. Inst., Agric. Res. Cent., Giza, Egypt. \\ ${ }^{3}$ Plant Pathol. Res. Inst., Agric. Res. Cent., Giza, Egypt.
}

\begin{abstract}
Two faba bean (Vicia faba L.) cultivars namely Giza 716 and Giza 40 were investigated for their response to foliar application with some botanical extracts and salicylic acid to improve vegetative growth, yield, and its relation to chocolate spot disease caused by Botrytis fabae Sard. Garlic cloves (GE), onion bulb (OE), eucalyptus leaves (EE) extracts (50 and $100 \mathrm{ml} / \mathrm{L}$ ) and salicylic acid (SA 100 and $200 \mathrm{ppm}$ ) were used during two successive seasons of 2017/2018 and 2018/2019 at Etay El-Baroud Agricultural Research Station Farm, El-Beheira Governorate. Under field conditions Giza 716 had better values of growth, agronomic parameters and higher leaves content of chlorophyll a, b, $(a+b)$, seed content of total carbohydrates \%, protein $\%$, leaves peroxidase and catalase activities and total phenols in both seasons. GE, OE, EE and SA increased faba bean growth and yield compared to Mancozeb and control treatments. SA $200 \mathrm{ppm}$ increased leaf area /plant after 95 days in the first season. It had the first grade of shoot dry weight after 75 and 95 days and seed weight/plant in the second season and increased leaf area /plant after 75 days, plant height, number of branches/plant, number of pods/plant, 100 seed weight and seed yield/fed in both seasons. It increased chlorophyll a in the first season, chlorophyll $\mathrm{b}$ in the second season and chlorophyll $\mathrm{a}+\mathrm{b}$ in both seasons. As well as, it had the highest catalase activity, total phenols content and protein \%. In this respect, GE $100 \mathrm{ml} / \mathrm{L}$ significantly increased shoot dry weight /plant after 75 days and leaf area/plant after 95 days in the first and second seasons, respectively. It significantly increased shoot dry weight/plant after 95 days and seed weight/plant in the first season only compared to Mancozeb and control treatments. B. fabae spore suspension was applied using two techniques; foliar spray and droplet on leaflets. Using detached leaf test in the laboratory, Giza 716 had lower disease severity \% (DS \%) and spot diameter than Giza 40. In case of spore suspension foliar spray technique the treatments of GE $100 \mathrm{ml} / \mathrm{L}, \mathrm{SA} 200 \mathrm{ppm}$ and Mancozeb had the least DS \%. In case of spore suspension droplet technique the treatments of OE 50 and OE $100 \mathrm{ml} / \mathrm{L}$ and Mancozeb had the least spot diameter values. Under field conditions, disease severity increased with increasing periods from 75 to 105 days. Giza 716 had the lower DS \% after 75, 90 and 105 days from sowing in both seasons than Giza 40. SA 200 ppm and OE $100 \mathrm{ml} / \mathrm{L}$ had the lowest DS \% values in the first and second seasons, respectively.
\end{abstract}

Key words: Faba bean, Botanical extracts, Salicylic acid, Growth, Yield, Peroxidase, Catalase, Phenols, Detached leaf, Chocolate spot severity

\section{INTRODUCTION}

Faba bean (Vicia faba L.) is considered as one of the most profitable field crops in Egypt and grown mainly for its green pods and dried seeds, which are rich in a protein and other compounds (Nassib et al., 1991). It breaks disease cycles of cereals, and adds high amounts of fixed nitrogen to soils (Baka et al., 2012).

Chocolate spot, which caused by Botrytis fabae Sard., is one of the most yield limiting constraints of faba bean worldwide (Torres et al., 2004), as in the northern region of the Nile Delta of Egypt, where low temperature and high relative humidity favoring its spread are dominant (El-Banoby et al., 2013) cause severe yield losses reach 60-80\% among the susceptible cultivars (Mbazia et al., 2016). It decreases the total carbohydrates, nitrogen, protein and nucleic acid (DNA and RNA) contents of yielded seeds (Aldesuquy, 2015).

Fungicides extensive applications had a harmful effect such as an appearance of new fungicide- resistant pathogenic strains, contamination of the environment and modification of the balance of the beneficial microorganisms (Tola et al., 2016). Plants are a store house of natural compounds that share in inhibiting phytopathogens (Sales et al., 2016) and these are less persistent and hence easily biodegradable, thus are considered safe to the environment and human health compared to the synthetic ones (Pattnaik et al., 2012). The active principles components in plant extracts may either act on the pathogen directly (Amadioha, 2000) or induce systemic resistance in host plants causing a reduction of the disease development (Kagale et al., 2004).

Garlic (Allium sativum L.) has at least 100 types of sulfuric compositions and $70-80 \%$ of them are constituted of allicins (Murray et al., 2012) and different bioactive compounds, such as alliin, diallyl sulfide, diallyl disulfide, diallyl trisulfide, ajoene, and S-allyl-cysteine (Shang et al., 2019). ElSaadony et al. (2017) reported that spraying pea plants with garlic extract $(5 \%)$ had a significant effect in most agronomic traits. 
The onion (Allium cepa) extract contains plant growth hormones which positively influenced the root growth and plant height of chrysanthemum (Purwitasari, 2012). Antimicrobial properties of onion (A. серa) have been reported by many researchers such as Irkin and Korukluoglu (2007) against Aspergillus niger and Carnago et al. (2011) against Fusarium oxysporum and Colletotrichum.

Alabi et al. (2005) revealed that the use of Eucalyptus globulus extract had positive effect on the agronomic traits of cowpea. Also Tola et al. (2016) reported that crude extract of leaves of $E$. globulus have natural fungitoxic potential for the control of $B$. fabae and stimulating effect on some faba bean agronomic traits.

Salicylic acid (SA) plays an important role in controlling plant growth and development, pigment content, photosynthesis and transpiration rate, ion uptake and transport, seed germination, fruit yield, glycolysis and inducing changes in leaf anatomy and chloroplast ultrastructure (Jayakannan et al., 2015). Many investigators exhibited significant reduction of chocolate spot disease severity of faba bean caused by Botrytis fabae when using salicylic acids (Aldesuquy et al., 2014 and El-Sayed, 2017).

El-Hendawy et al. (2010) stated that there was a significant increase in the activity of peroxidase (PO) and polyphenol oxidase (PPO) after treatment of wheat, sugar beet and faba bean plants with salicylic acid. The enhanced peroxidase activity induced systemic resistance in plants against several pathogens (Baysal et al., 2005) and associated with a number of physiological functions that may contribute resistance against Fusarium wilt of banana (Thakker et al., 2013). Catalase (CAT) is an important enzyme that protects the plant cells from oxidative damage by reactive oxygen species (ROS) (Gill and Tuteja, 2010). Plant phenolics increase the rigidity of plant cell wall acting as molecular bridge between cell wall components (Ozyigit, 2008).

The aim of this study was planned to evaluate the effect of spraying garlic cloves, onion bulb, eucalyptus leaves extracts and salicylic acid as alternative chemicals on faba bean growth, yield, some chemical components and its effect on chocolate spot disease severity caused by Botrytis fabae under laboratory and field conditions.

\section{MATERIALS AND METHODS}

The present study was carried out at the experimental farm of Itay El-Baroud Agricultural Research Station during the two successive seasons of 2017/2018 and 2018/2019.

\section{Field Experiment}

The experiment was conducted in split-plot design with four replicates where the two faba beans cultivars, Giza 716 (resistant) and Giza 40 (susceptible), were chosen for this study and arranged in the main plots and the ten treatments mentioned in Table (1) in the sub-plots. Seeds of faba bean cultivars used in this investigation were obtained from Legumes Dept., Field Crops Res. Institute, Agric. Res. Center, Giza, Egypt. The plot size was 5 ridges each ridge was three meters long and $70 \mathrm{~cm}$ apart. Seeds were planted in two sides of the ridge at $15 \mathrm{~cm}$ hill spacing with one seed per hill. Faba bean seeds were sown in $5^{\text {th }}$ and $3^{\text {th }}$ of November 2017 and 2018, respectively and all the other cultural practices were carried out according to the recommendations of Ministry of Agriculture and Land Reclamation, Egypt.

\section{Preparation of extracts}

All extracts were prepared by grinding $500 \mathrm{~g}$ of plant materials of garlic gloves, red onion and eucalyptus dry leaves in $1000 \mathrm{ml}$ distilled water. The filtrate was used for preparation of different concentrations, i.e., 50 and $100 \mathrm{ml} / \mathrm{L}$. Such preparation techniques of garlic and onion from one hand and eucalyptus from another hand were carried out according to Dahab et al., (2018) and Tola et al., (2016), respectively.

\section{Foliar Spraying of the Treatments}

Faba bean plants were sprayed with the previous plant extracts and salicylic acid three times at ages of 30, 45 and 60 days during the two seasons. The fungicide (Mancozeb) was used at the rate of $250 \mathrm{~g} / 100 \mathrm{~L}$ as a positive control while a tap water was used as negative control (Table 1).

Table 1: Foliar spraying treatments

\begin{tabular}{ll}
\hline Abbreviation & Foliar spraying treatments \\
\hline GE 50 & Garlic cloves extract $50 \mathrm{ml} / \mathrm{L}$ \\
\hline GE100 & Garlic cloves extract $100 \mathrm{ml} / \mathrm{L}$ \\
\hline OE 50 & Onion bulb extract $50 \mathrm{ml} / \mathrm{L}$ \\
\hline OE 100 & Onion bulb extract $100 \mathrm{ml} / \mathrm{L}$ \\
\hline EE 50 & Eucalyptus leaves extract $50 \mathrm{ml} / \mathrm{L}$ \\
\hline EE 100 & Eucalyptus leaves extract $100 \mathrm{ml} / \mathrm{L}$ \\
\hline SA 100 & Salicylic acid $100 \mathrm{ppm}$ \\
\hline SA 200 & Salicylic acid $200 \mathrm{ppm}$ \\
\hline M & Mancozeb $250 \mathrm{~g} / 100 \mathrm{~L}($ positive control) \\
\hline C & Water (negative control) \\
\hline
\end{tabular}




\section{Character measurements \\ Growth characters}

Shoot dry weight / plant (g) and leaf area / plant $\left(\mathrm{cm}^{2}\right)$ were estimated as the average of five plants chosen randomly at 75 and 90 days after sowing. To determine leaf area/plant (LA), the area of 10 disks $\left(10 \times 3.14 \times(1.5)^{2}\right)=70.65 \mathrm{~cm}^{2}$ was calculated and the leaf area was determined according to Hunt (1990) using the following formula:

\section{$\mathrm{LA}=70.65 \frac{\text { dry weight of leaves per plant }}{\text { dry weight of leaves disks }}$}

Plant samples were dried in an electric oven with drift fan at $70^{\circ} \mathrm{C}$ for $48 \mathrm{~h}$, till constant dry weight.

\section{Yield and its attributes}

At harvesting time (after 165 and 163 days from sowing in the first and second seasons, respectively), ten plants from central row in each sub-plot were randomly taken to determine plant height $(\mathrm{cm})$, number of branches/plant, number of pods/plant, 100-seed weight $(\mathrm{g})$, and seed weight/plant $(\mathrm{g})$. Plants in the central area of each sub-plot were harvested and weighed then converted to seed yield $(\mathrm{kg} / \mathrm{fed})$.

\section{Physiological traits}

\section{Determination of leaf chlorophyll}

Leaves were selected from different positions on the faba bean stem after 75 days from sowing date and homogenized in $5 \mathrm{ml}$ of $85 \%$ cold acetone and centrifuged. The extract was measured spectrophotometrically at 663 and $647 \mathrm{~nm}$ (Metzner et al., 1965). The chlorophyll content was then expressed as $\mathrm{mg} / \mathrm{g}$ fresh weight. The following equations were applied for determining the chlorophyll content of the leaf sample:

Chl a= $11.79\left(\mathrm{E}_{663}\right)-2.29\left(\mathrm{E}_{647}\right)$

Chl $b=20.05\left(E_{647}\right)-4.77\left(E_{663}\right)$

Determination of total carbohydrates and protein in dried seeds

Total carbohydrates were determined using phenol sulphuric method (Dubois et al., 1956). Total nitrogen percentage was determined by Modified Micro-Kjeldahl method as described by AOAC (1988) and the percentage of protein was calculated by multiplying total $\mathrm{N}$ values by factor 6.25 .

\section{Determination of enzyme activities}

The sample of one $\mathrm{g}$ of leaves (after 75 days from sowing) was homogenized in $8 \mathrm{ml}$ of $0.1 \mathrm{M}$ sodium phosphate buffer (SPB) $\mathrm{pH} 6.5$ at $4^{\circ} \mathrm{C}$. The filtrate was centrifuged at 20,000 rpm for $15 \mathrm{~min}$. The supernatant served as an enzyme extract for enzyme assay of peroxidase and catalase.

\section{Peroxidase (PO) activity}

Peroxidase activity was assayed colorimetrically according to the method described by Amako et al. (1994). The increase in optical density at $430 \mathrm{~nm}$ against blank was continuously recorded every minute. Peroxidase enzyme activity was expressed as change in absorbance at $430 \mathrm{~nm}$ per $\mathrm{min} / \mathrm{g}$ fresh leaves.

\section{Catalase (CAT) activity}

Catalase activity was assayed by measuring the rate of disappearance of $\mathrm{H}_{2} \mathrm{O}_{2}$ at $240 \mathrm{~nm}$ according to the methods of Cakmak and Horst (1991). The decrease in absorbance at $240 \mathrm{~nm}$ was recorded for $1 \mathrm{~min}$ by spectrophotometer. One unit was defined as the amount of enzyme necessary to decompose 1 mmol $\mathrm{H}_{2} \mathrm{O}_{2} / \mathrm{min} / \mathrm{g}$ fresh leaves under the conditions of the assay.

\section{Determination of total phenols}

Total phenols at 75 days from sowing were determined using the colorimetric method described by Folin and Ciocalteau (Singleton and Rossi, 1965). Total phenols content was then expressed as $\mathrm{mg} / \mathrm{g}$ fresh leaves.

Isolation and identification of the causal organism

Samples of naturally infected faba bean leaves were used for isolation of chocolate spot pathogen. Infected leaflets having symptoms were cut into small pieces, each with single lesion of the concerned disease, surface was sterilized by immersing them in $1 \%$ sodium hypochlorite solution for $2 \mathrm{~min}$, rinsed in sterile water and dried between double layers of sterile filter paper. The samples were plated on Potato Dextrose Agar (PDA) plates. Four pieces were put in each plate then incubated at $20^{\circ} \mathrm{C}$ for one week. Pure isolates were obtained using single spore technique (Haggag et al., 2006).

Fungal culture and inoculum preparation

To induce sporulation, the fungal culture was transferred to Faba Leaf Dextrose Agar (FLDA) medium (extract of $400 \mathrm{~g}$ of faba bean leaves, $18 \mathrm{~g}$ agar and $20 \mathrm{~g}$ dextrose and the volume made up to 1L). The composition was then autoclaved at a temperature of $121^{\circ} \mathrm{C}$ and pressure of $15 \mathrm{p}$. s. i. for $20 \mathrm{~min}$, cooled down to about $45^{\circ} \mathrm{C}$ and poured into sterilized $9 \mathrm{~cm}$ diameter Petri dishes (Haggag et al., 2006) and incubated at $20{ }^{\circ} \mathrm{C}$ in a cycle of $12 \mathrm{~h}$ darkness and $12 \mathrm{~h}$ visible light to induce sporulation for 15 days at $20-22^{\circ} \mathrm{C}$ as described by (Derckel et al., 1999). Conidia were collected by washing plates with 4-5 $\mathrm{ml}$ of sterile distilled water, and the resulting spore suspension was adjusted to $3 \times 10^{6}$ conidia/ml using a hemocytometer (Bouhassan et al., 2004).

Determination of chocolate spot disease severity using detached leaf test in vitro

In the second season, after $24 \mathrm{~h}$ from the last spray with the tested compounds (Table 1) under field conditions, fully expanded leaflets of similar age group were detached from the middle nodes of the two cultivars. Leaflets were surface disinfected by $1 \%$ sodium hypochlorite for $2 \mathrm{~min}$, and subsequently rinsed with distilled sterile water and allowed to dry on sterile filter paper. The cut end of each leaflet petiole is covered with moistened cotton 
to maintain leaves at maximum turgor. This experiment was divided in two groups: at the first group, one drop $(20 \mu \mathrm{l})$ of the fungal spore suspension was placed near the midrib of the leaflets, and at the second group B. fabae spore suspension sprayed with $1 \mathrm{ml} / 4$ leaflets/replicate (Taffa et al., 2013). Each treatment had three replicates each one had four leaflets. The benches are then covered with polythene sheets and left at room temperature $\left(20 \pm 2{ }^{\circ} \mathrm{C}\right)$ for 5-6 days till disease is assessed. A 1-4 scale can be used (ICARDA, 1986), where 1: no infection or very small flecks (1-25\% necrosis); 2: necrotic flecks with few small lesions (26-50\% necrosis), and very poor sporulation; 3: medium coalesced lesions (51$75 \%$ necrosis) with intermediate sporulation; 4: large coalesced lesions (76-100\% necrosis) with abundant sporulation. Diameters of emerging lesions were measured after 6 days.

Disease severity $\%=[\Sigma(\mathrm{n} \times \mathrm{v}) / 4 \mathrm{~N}] \times 100$

Where: $(n)=$ Number of plants in each category; $(v)$ $=$ Numerical values of symptoms category; $(\mathrm{N})$ $=$ Total number of plants; (4) = Maximum numerical value of symptom category.

Determination of chocolate spot disease severity under field conditions

Severity due to natural infection was determined after 75, 90 and 105 days from sowing. Ten randomly pre-tagged faba bean plants in the three central rows, disease severity on leaves was rated using 1-9 rating scale (Bernier et al., 1993), where 1: no disease symptoms or very small specks; 3: few small discrete lesions; 5: some coalesced lesions with some defoliation; 7: large coalesced sporulating lesions, $50 \%$ defoliation and some dead plant; and 9: extensive lesions on leaves, stems and pods, severe defoliation, heavy sporulation, stem girdling, blackening and death of more than $80 \%$ of plants (Bernier et al., 1984). Chocolate spot disease severity \% was assessed according to the following formula:

Disease severity $\%=[\Sigma(\mathrm{n} \times \mathrm{v}) / 9 \mathrm{~N}] \times 100$

Where: $(\mathrm{n})=$ Number of plants in each category; (v) = Numerical values of symptoms category; $(\mathrm{N})=$ Total number of plants; $(9)=$ Maximum numerical value of symptom category.

Then efficacy percentage (E \%) of each compound in reducing disease severity percentage of faba bean was assessed according to the equation adapted by Rewal and Jhooty (1985) as follow:-

$\mathrm{E} \%=(\mathrm{C}-\mathrm{T} / \mathrm{C}) \times 100$

Where: $\mathrm{C}=$ Disease severity $\%$ in control; $\mathrm{T}=$ Disease severity $\%$ in the treatment

\section{Statistical Analysis}

All data were subjected to the analyses of variance (ANOVA) for split-plot design followed by compared means with LSD at level probability 5\% according to (Gomez and Gomez, 1984).

\section{RESULTS AND DISCUSSION}

\section{Growth characters}

Effect of foliar spraying treatments on cultivars and their interaction for faba bean shoot dry weight/plant after 75 and 95 days from sowing

Data in Table (2) appear that Giza $716 \mathrm{cv}$. had higher shoot dry weight/plant after 75 and 95 days from sowing in both seasons than Giza 40 with averages (9.28 and $9.72 \mathrm{~g}$ ) and (17.44 and 17.36 g), respectively.

The results showed that spraying botanical extracts and SA significantly increased shoot dry weight compared to Mancozeb and control treatments (Table 2). At the first season, after 75 days it can be noticed that GE $100 \mathrm{ml} / \mathrm{L}$ had the first grade followed by SA $200 \mathrm{ppm}$ with averages of (9.96 and $9.78 \mathrm{~g}$ ) and after 95 days OE $100 \mathrm{ml} / \mathrm{L}$ had the first grade followed by SA $200 \mathrm{ppm}$ with averages of (18.66 and $18.38 \mathrm{~g})$, respectively. These results were similar with those of garlic extract on dwarf umbrella tree (Schefflera arboricola) plants (Hanafy et al., 2012). These founding's might relate to the content garlic extract of nutrients, vitamins and some other compounds, which encourage the production of plant hormones such as gibberellins and cytokinins and eventually lead to an increase in plant growth (Al-Mayahi and Fayadh, 2015). At the second season, SA $200 \mathrm{ppm}$ had the highest value after 75 days followed by GE $100 \mathrm{ml} / \mathrm{L}$ with averages of (10.50 and 10.21g) and SA $200 \mathrm{ppm}$ had the highest value after 95 days followed by GE $100 \mathrm{ml} / \mathrm{L}$ with averages of $(17.93$ and $17.90 \mathrm{~g})$, respectively. These results are in agreement with the findings mentioned by Aldesuquy (2015) and ElAwadi et al. (2017) who reported that spraying faba bean plants with salicylic acid significantly increased dry weight of shoot system compared with non-sprayed (control) plants. In this respect, spraying sugar beet and pea plants with salicylic acid or garlic extract had a positive significant effect on plant growth (Youssef et al., 2016 and ElSaadony et al., 2017). The promotive effect of salicylic acid could be attributed to its bio regulator effects on physiological and biochemical processes in plants such as ion uptake, cell elongation, cell division, cell differentiation (El-Tayeb, 2005).

For the interaction effect, at the first season Giza 716 x GE $100 \mathrm{ml} / \mathrm{L}$ had the highest shoot dry weight after 75 day followed by Giza 716 x SA 200 ppm and the same treatments at the second season after 95 days. 
Table 2: Effect of foliar spraying treatments on cultivars and their interaction for faba bean shoot dry weight/plant after 75 and 95 days from sowing during two successive seasons under field conditions.

\begin{tabular}{|c|c|c|c|c|}
\hline \multirow{3}{*}{$\begin{array}{ll}\text { Parameter } & \\
& \text { Season }\end{array}$} & \multicolumn{2}{|c|}{$\begin{array}{c}\text { Shoot dry weight/ plant after } 75 \\
\text { days (g) }\end{array}$} & \multicolumn{2}{|c|}{$\begin{array}{c}\text { Shoot dry weight/ plant after } 95 \\
\text { days (g) }\end{array}$} \\
\hline & $2017 / 2018$ & $2018 / 2019$ & $2017 / 2018$ & $2018 / 2019$ \\
\hline & & & & \\
\hline \multicolumn{5}{|c|}{ Cultivar (C) } \\
\hline Giza 716 & $9.28^{\mathrm{a}}$ & $9.72^{\mathrm{a}}$ & $17.44^{\mathrm{a}}$ & $17.36^{\mathrm{a}}$ \\
\hline Giza 40 & $7.57^{\mathrm{b}}$ & $7.59^{b}$ & $14.94^{\mathrm{b}}$ & $15.04^{\mathrm{b}}$ \\
\hline \multicolumn{5}{|c|}{ Foliar spray (F) } \\
\hline $\mathrm{GE} 50 \mathrm{ml} / \mathrm{L}$ & $8.25^{\mathrm{bc}}$ & $8.70^{\mathrm{b}}$ & $17.30^{\mathrm{ab}}$ & $16.95^{\mathrm{a}}$ \\
\hline $\mathrm{GE} 100 \mathrm{ml} / \mathrm{L}$ & $9.96^{\mathrm{a}}$ & $10.21^{\mathrm{a}}$ & $17.24^{\mathrm{ab}}$ & $17.90^{\mathrm{a}}$ \\
\hline $\mathrm{OE} 50 \mathrm{ml} / \mathrm{L}$ & $8.59^{\mathrm{b}}$ & $8.19^{\mathrm{b}}$ & $15.59^{\mathrm{b}}$ & $16.79^{\mathrm{a}}$ \\
\hline $\mathrm{OE} 100 \mathrm{ml} / \mathrm{L}$ & $9.53^{\mathrm{a}}$ & $9.33^{\mathrm{ab}}$ & $18.66^{\mathrm{a}}$ & $17.58^{\mathrm{a}}$ \\
\hline EE $50 \mathrm{ml} / \mathrm{L}$ & $7.77^{\mathrm{b}}$ & $8.57^{\mathrm{b}}$ & $15.87^{\mathrm{b}}$ & $14.89^{\mathrm{b}}$ \\
\hline EE $100 \mathrm{ml} / \mathrm{L}$ & $8.62^{b}$ & $9.02^{b}$ & $17.31^{\mathrm{ab}}$ & $17.78^{\mathrm{a}}$ \\
\hline SA 100 ppm & $8.45^{\mathrm{b}}$ & $8.78^{\mathrm{b}}$ & $16.84^{\mathrm{ab}}$ & $16.54^{\mathrm{a}}$ \\
\hline SA $200 \mathrm{ppm}$ & $9.78^{\mathrm{a}}$ & $10.50^{\mathrm{a}}$ & $18.38^{\mathrm{a}}$ & $17.93^{\mathrm{a}}$ \\
\hline Mancozeb & $7.50^{\mathrm{c}}$ & $7.06^{\mathrm{c}}$ & $13.05^{\mathrm{c}}$ & $13.43^{\mathrm{bc}}$ \\
\hline Control & $5.80^{\mathrm{d}}$ & $6.20^{c}$ & $11.70^{\mathrm{c}}$ & $12.2^{\mathrm{bc}}$ \\
\hline \multicolumn{5}{|c|}{ Interaction $(\mathrm{C} \times \mathrm{F})$} \\
\hline \multicolumn{5}{|l|}{ Giza 716} \\
\hline $\mathrm{GE} 50 \mathrm{ml} / \mathrm{L}$ & 9.21 & 10.14 & 19.14 & 18.60 \\
\hline $\mathrm{GE} 100 \mathrm{ml} / \mathrm{L}$ & 11.14 & 11.69 & 18.39 & 20.09 \\
\hline $\mathrm{OE} 50 \mathrm{ml} / \mathrm{L}$ & 9.98 & 9.46 & 17.27 & 17.87 \\
\hline $\mathrm{OE} 100 \mathrm{ml} / \mathrm{L}$ & 10.47 & 10.58 & 20.17 & 18.35 \\
\hline EE 50 ml/L & 8.43 & 9.27 & 17.20 & 16.35 \\
\hline EE $100 \mathrm{ml} / \mathrm{L}$ & 9.16 & 10.24 & 18.26 & 18.23 \\
\hline SA 100 ppm & 9.70 & 9.89 & 17.82 & 18.0 \\
\hline SA 200 ppm & 10.94 & 11.80 & 20.79 & 19.65 \\
\hline Mancozeb & 7.43 & 7.62 & 13.69 & 13.67 \\
\hline Control & 6.36 & 6.54 & 11.79 & 12.05 \\
\hline \multicolumn{5}{|l|}{ Giza 40} \\
\hline GE 50 ml/L & 7.31 & 7.27 & 15.47 & 15.20 \\
\hline $\mathrm{GE} 100 \mathrm{ml} / \mathrm{L}$ & 8.78 & 8.74 & 16.10 & 15.71 \\
\hline $\mathrm{OE} 50 \mathrm{ml} / \mathrm{L}$ & 7.20 & 6.92 & 13.93 & 14.98 \\
\hline $\mathrm{OE} 100 \mathrm{ml} / \mathrm{L}$ & 8.34 & 8.09 & 17.16 & 16.83 \\
\hline EE $50 \mathrm{ml} / \mathrm{L}$ & 7.12 & 7.89 & 14.55 & 13.43 \\
\hline EE $100 \mathrm{ml} / \mathrm{L}$ & 8.09 & 7.82 & 16.38 & 17.34 \\
\hline SA 100 ppm & 7.22 & 7.68 & 15.87 & 15.09 \\
\hline SA 200 ppm & 8.63 & 9.21 & 15.97 & 16.21 \\
\hline Mancozeb & 6.05 & 6.52 & 12.42 & 13.20 \\
\hline Control & 5.25 & 5.88 & 11.62 & 12.49 \\
\hline L.S.D $0.05(\mathrm{C})$ & 0.29 & 0.51 & 1.66 & 1.21 \\
\hline L.S.D $0.05(\mathrm{~F})$ & 0.90 & 0.98 & 1.45 & 1.57 \\
\hline L.S.D $0.05(\mathrm{C} \times \mathrm{F})$ & 1.27 & $\mathrm{NS}$ & $\mathrm{NS}$ & 2.23 \\
\hline
\end{tabular}

Means in the same column followed by the same letter(s) are not significant according to L.S.D at the probability of 0.05 .

Effect of foliar spraying treatments on cultivars and their interaction for faba bean leaf area/plant $\left(\mathrm{cm}^{2}\right)$ after 75 and 95 days from sowing

Data present in Table (3) reveal that leaf area/ plant was significantly differ by cultivars at 75 and 95 days from sowing during the two growing seasons. It can be noticed that Giza $716 \mathrm{cv}$. had higher leaf area/plant after 75 and 95 days than Giza 40; these were 707.81 and $702.03 \mathrm{~cm}^{2}$ and 1753.05 and $1814.30 \mathrm{~cm}^{2}$ in the first and second seasons, respectively. 
Table 3: Effect of foliar spraying treatments on cultivars and their interaction for faba bean leaf area/plant $\left(\mathrm{cm}^{2}\right)$ after 75 and 95 days from sowing during two successive seasons under field conditions.

\begin{tabular}{|c|c|c|c|c|}
\hline \multirow[t]{2}{*}{ Parameter } & \multicolumn{2}{|c|}{$\begin{array}{l}\text { Leaf area/plant after } 75 \text { days } \\
\left(\mathrm{cm}^{2}\right)\end{array}$} & \multicolumn{2}{|c|}{$\begin{array}{l}\text { Leaf area/plant after } 95 \text { days } \\
\left(\mathrm{cm}^{2}\right)\end{array}$} \\
\hline & $2017 / 2018$ & 2018/2019 & 2017/2018 & $2018 / 2019$ \\
\hline Factor & & & & \\
\hline \multicolumn{5}{|c|}{ Cultivar (C) } \\
\hline Giza 716 & $707.81^{\mathrm{a}}$ & $702.03^{\mathrm{a}}$ & $1753.05^{\mathrm{a}}$ & $1814.30^{\mathrm{a}}$ \\
\hline Giza 40 & $548.88^{\mathrm{b}}$ & $557.21^{\mathrm{b}}$ & $1432.13^{b}$ & $1422.30^{\mathrm{b}}$ \\
\hline \multicolumn{5}{|c|}{ Foliar spray (F) } \\
\hline $\mathrm{GE} 50 \mathrm{ml} / \mathrm{L}$ & $626.17^{\mathrm{ab}}$ & $642.47^{\mathrm{a}}$ & $1517.63^{\mathrm{bc}}$ & $1581.13^{\mathrm{b}}$ \\
\hline $\mathrm{GE} 100 \mathrm{ml} / \mathrm{L}$ & $651.55^{\mathrm{a}}$ & $666.61^{\mathrm{a}}$ & $1692.57^{\mathrm{ab}}$ & $1888.29^{\mathrm{a}}$ \\
\hline $\mathrm{OE} 50 \mathrm{ml} / \mathrm{L}$ & $615.43^{\mathrm{ab}}$ & $606.32^{\mathrm{ab}}$ & $1592.07^{\mathrm{b}}$ & $1617.06^{\mathrm{b}}$ \\
\hline $\mathrm{OE} 100 \mathrm{ml} / \mathrm{L}$ & $676.54^{\mathrm{a}}$ & $694.12^{\mathrm{a}}$ & $1793.18^{\mathrm{a}}$ & $1793.91^{\mathrm{a}}$ \\
\hline $\mathrm{EE} 50 \mathrm{ml} / \mathrm{L}$ & $629.90^{\mathrm{a}}$ & $646.23^{\mathrm{a}}$ & $1488.61^{\mathrm{bc}}$ & $1563.70^{\mathrm{b}}$ \\
\hline $\mathrm{EE} 100 \mathrm{ml} / \mathrm{L}$ & $658.16^{\mathrm{a}}$ & $657.26^{\mathrm{a}}$ & $1786.58^{\mathrm{a}}$ & $1779.55^{\mathrm{ab}}$ \\
\hline SA $100 \mathrm{ppm}$ & $683.40^{\mathrm{a}}$ & $646.72^{\mathrm{a}}$ & $1552.56^{\mathrm{bc}}$ & $1644.28^{\mathrm{b}}$ \\
\hline SA $200 \mathrm{ppm}$ & $694.13^{\mathrm{a}}$ & $610.27^{\mathrm{a}}$ & $1798.70^{\mathrm{a}}$ & $1866.54^{\mathrm{a}}$ \\
\hline Mancozeb & $548.84^{\mathrm{b}}$ & $544.06^{\mathrm{ab}}$ & $1407.78^{c}$ & $1399.73^{c}$ \\
\hline Control & $499.32^{\mathrm{b}}$ & $483.15^{\mathrm{b}}$ & $1296.70^{c}$ & $1298.80^{c}$ \\
\hline \multicolumn{5}{|c|}{ Interaction $(\mathrm{C} \times \mathrm{F})$} \\
\hline \multicolumn{5}{|c|}{ Giza 716} \\
\hline GE $50 \mathrm{ml} / \mathrm{L}$ & 709.33 & 689.32 & 1656.95 & 1789.89 \\
\hline $\mathrm{GE} 100 \mathrm{ml} / \mathrm{L}$ & 692.13 & 721.13 & 1827.71 & 2191.70 \\
\hline $\mathrm{OE} 50 \mathrm{ml} / \mathrm{L}$ & 685.48 & 672.84 & 1684.91 & 1726.64 \\
\hline $\mathrm{OE} 100 \mathrm{ml} / \mathrm{L}$ & 805.58 & 783.82 & 1979.55 & 1951.92 \\
\hline $\mathrm{EE} 50 \mathrm{ml} / \mathrm{L}$ & 704.98 & 737.96 & 1662.92 & 1640.80 \\
\hline EE $100 \mathrm{ml} / \mathrm{L}$ & 747.87 & 719.14 & 1984.64 & 1970.38 \\
\hline SA 100 ppm & 771.60 & 763.94 & 1716.98 & 1763.44 \\
\hline SA 200 ppm & 799.54 & 838.38 & 2026.14 & 2101.63 \\
\hline Mancozeb & 578.88 & 591.77 & 1562.17 & 1566.23 \\
\hline Control & 549.17 & 502.27 & 1428.59 & 1440.39 \\
\hline \multicolumn{5}{|c|}{ Giza 40} \\
\hline GE $50 \mathrm{ml} / \mathrm{L}$ & 543.03 & 546.13 & 1378.31 & 1372.38 \\
\hline $\mathrm{GE} 100 \mathrm{ml} / \mathrm{L}$ & 610.99 & 612.11 & 1557.44 & 1584.89 \\
\hline $\mathrm{OE} 50 \mathrm{ml} / \mathrm{L}$ & 545.39 & 539.81 & 1499.25 & 1507.50 \\
\hline $\mathrm{OE} 100 \mathrm{ml} / \mathrm{L}$ & 547.51 & 602.44 & 1606.83 & 1635.90 \\
\hline EE $50 \mathrm{ml} / \mathrm{L}$ & 554.84 & 554.51 & 1314.32 & 1486.62 \\
\hline $\mathrm{EE} 100 \mathrm{ml} / \mathrm{L}$ & 568.46 & 595.39 & 1588.54 & 1588.74 \\
\hline SA 100 ppm & 595.22 & 529.76 & 1388.16 & 1525.13 \\
\hline SA $200 \mathrm{ppm}$ & 587.42 & 582.17 & 1571.27 & 1631.46 \\
\hline Mancozeb & 486.53 & 496.36 & 1253.41 & 1233.24 \\
\hline Control & 449.48 & 439.04 & 1163.83 & 1157.23 \\
\hline L.S.D $0.05(\mathrm{C})$ & 43.61 & 85.82 & 96.48 & 45.86 \\
\hline L.S.D $0.05(F)$ & 79.53 & 107.71 & 179.44 & 143.50 \\
\hline L.S.D $0.05(\mathrm{C} \times \mathrm{F})$ & NS & NS & NS & NS \\
\hline
\end{tabular}

Means in the same column followed by the same letter(s) are not significant according to L.S.D at the probability of 0.05 .

The results indicated that spraying GE, OE, EE (50 and $100 \mathrm{ml} / \mathrm{L})$ and SA (100 and $200 \mathrm{ppm})$ significantly increased faba bean leaf area/plant compared to Mancozeb and control treatments. In this respect El-Saadony et al. (2017) found that foliar spray with SA or GE increased pea leaf area. Similar results were obtained with garlic extract on Schefflera arboricola plants (Hanafy et al., 2012). These results might relate to garlic contains vitamins, minerals, flavonoids, ascorbic acid, sulphur and trace of iodine (Azzini et al., 2014). 
Foliar spraying of SA 200 ppm had the highest mean values of leaf area with averages of $\left(694.13\right.$ and $\left.610.27 \mathrm{~cm}^{2}\right)$, respectively after 75 days in the two seasons and at the first season only after 95 days with an average of $\left(1798.70 \mathrm{~cm}^{2}\right)$. These results were in harmony with Aldesuquy (2015) whom stated that foliar spray of faba bean plants with SA increased leaf area. OE $100 \mathrm{ml} / \mathrm{L}$ treatment had the second grade of this trait with averages of (676.54 and $694.12 \mathrm{~cm}^{2}$ ) after 75 days in the two seasons, respectively and $\left(1793.18 \mathrm{~cm}^{2}\right)$ after 95 days in the first season only. Asad Ullah et al. (2019) reported that foliar spraying with salicylic acid significantly increased tomato leaf area. Ibrahim et al. (2019) found that foliar application of salicylic acid significantly increased vegetative growth, fruit yield, and quality of red sweet pepper as compared with the control plants.

The role of SA on the leaf area attributes to its important roles on activating cell division, biosynthesis of organic foods and availability as well as movement of mineral nutrients towards the leaves (Shaaban et al., 2011).

\section{Yield and its attributes}

Effect of foliar spraying treatments on cultivars and their interaction for faba bean plant height (cm) and number of branches/plant

Data presented in Table (4) show that Giza 716 cv. had the taller plants than Giza 40 in both seasons with averages of (93.87 and $96.05 \mathrm{~cm})$, respectively. The same trend was cleared in case for number of branches/plant. Giza 716 had higher value than Giza 40. This result was in harmony with that mentioned by El-Shafey et al. (2019).

Tested botanical extracts and SA spraying treatments had significant effect in increasing faba bean height compared to control. These results were in close to that mentioned by El-Saadony et al. (2017) who reported that spraying pea plants with salicylic acid at $(100 \mathrm{ppm})$ had a positive effect in plant height. In case of number of branches/plant, the spraying treatments had desired effect in this parameter compared to control treatment except with the GE $50 \mathrm{ml} / \mathrm{L}$ treatment in the first season only. Asad Ullah et al. (2019) reported that foliar spray with SA significant increased number of tomato branches/plant. Noreen and Ashraf (2008) suggested that growth enhancement of SA treated plants might be due to the influence of SA in inducing changes in photosynthesis, antioxidant capacity and ion homeostasis processes.

In the considerable of the interaction treatments, data recorded significant effect for number in branches in the second season only. Giza 716 x SA 200 ppm had the best value of number of branches/plant.
Effect of foliar spraying treatments on cultivars and their interaction for faba bean number of pods/plant and seed weight/plant

Data mentioned in Table (5) show that Giza $716 \mathrm{cv}$. had higher number of pods/plant in the second season and seed weight/plant in both seasons than Giza 40 with averages of (11.97) and (23.02 and $24.48 \mathrm{~g}$ ), respectively. These results are in agreement with the findings reported by El-Shafey et al. (2019).

In case of spraying treatments, SA $200 \mathrm{ppm}$ significantly had the highest number of pods/plant in both seasons with averages of (11.15 and 13.82) and seed weight/plant with an average of (25.91 g) in the second season only. These results are in agreement with the findings reported by Asad Ullah et al. (2019) who reported that foliar spray with salicylic acid significantly increased number of tomato fruit/plant and yield/plant. Moreover, ElSaadony et al. (2017) reported that spraying pea plants with salicylic acid at (100 ppm) had a positive significant effect in number of pods per plant, number of seeds per pod and per plant. In this respect OE100 $\mathrm{ml} / \mathrm{L}$ had the first grade with seed weight/plant with an average of $(24.92 \mathrm{~g})$ in the first season only and the second grade in number of pods/plant in both seasons with averages of (10.53 and 12.07), respectively.

From the interaction, it clear that there are significant differences between the two tested cultivars and the spraying botanical extracts or salicylic acid in the first season only. Giza $40 \times$ SA $200 \mathrm{ppm}$ had the highest number of pods/plant followed by Giza 716 x OE $100 \mathrm{ml} / \mathrm{L}$ and Giza 716 x SA $200 \mathrm{ppm}$. In case of seed weight/plant Giza $716 \times$ OE $100 \mathrm{ml} / \mathrm{L}$ had the highest seed weight/plant in the first season followed by Giza 716 x EE $100 \mathrm{ml} / \mathrm{L}$ and Giza 716 x SA 200 ppm.

Effect of foliar spraying treatments on cultivars and their interaction for faba bean 100-seed weight (g) and seed yield/fed (kg)

Data presented in Table (6) show that Giza 716 cv. had higher 100- seed weight and seed yield/fed than Giza 40 in both seasons with averages of $(74.40$ and $83.61 \mathrm{~g})$ and (1645.95 and 1732.47 $\mathrm{kg} / \mathrm{fed}$ ), respectively.

In case of spraying treatments, the botanical extracts and salicylic acid treatments had significant increase in both parameters compared to control treatment. SA $200 \mathrm{ppm}$ had the highest $100 \mathrm{seed}$ weight followed by OE 100 and EE $100 \mathrm{ml} / \mathrm{L}$ in both seasons. These results are in close to that mentioned by Aldesuquy (2015) on faba bean plants. In case of seed yield/fed, SA 200 ppm had the highest value followed by GE 100 and OE 100 $\mathrm{ml} / \mathrm{L}$ with averages of $(1723.72,1699.05$ and $1670.87 \mathrm{~kg} / \mathrm{fed})$, respectively. 
Table 4: Effect of foliar spraying treatments on cultivars and their interaction for faba bean plant height $(\mathrm{cm})$ and number of branches/plant during two successive seasons under field conditions.

\begin{tabular}{|c|c|c|c|c|}
\hline \multirow[t]{2}{*}{ Parameter } & \multicolumn{2}{|c|}{ Plant height $(\mathrm{cm})$} & \multicolumn{2}{|c|}{ Number of branches/plant } \\
\hline & $2017 / 2018$ & 2018/2019 & $2017 / 2018$ & $2018 / 2019$ \\
\hline Factor & & & & \\
\hline \multicolumn{5}{|c|}{ Cultivar (C) } \\
\hline Giza 716 & $93.87^{\mathrm{a}}$ & $96.05^{\mathrm{a}}$ & 1.55 & $1.80^{\mathrm{a}}$ \\
\hline Giza 40 & $82.47^{\mathrm{b}}$ & $87.32^{\mathrm{b}}$ & 1.45 & $1.61^{b}$ \\
\hline \multicolumn{5}{|c|}{ Foliar spray (F) } \\
\hline $\mathrm{GE} 50 \mathrm{ml} / \mathrm{L}$ & $87.25^{\mathrm{ab}}$ & $88.75^{\mathrm{bc}}$ & $1.17^{\mathrm{b}}$ & $1.37^{\mathrm{d}}$ \\
\hline $\mathrm{GE} 100 \mathrm{ml} / \mathrm{L}$ & $92.12^{\mathrm{a}}$ & $95.75^{\mathrm{ab}}$ & $1.55^{\mathrm{ab}}$ & $1.62^{\mathrm{c}}$ \\
\hline $\mathrm{OE} 50 \mathrm{ml} / \mathrm{L}$ & $86.50^{\mathrm{ab}}$ & $90.87^{\mathrm{b}}$ & $1.35^{\mathrm{ab}}$ & $1.32^{\mathrm{d}}$ \\
\hline $\mathrm{OE} 100 \mathrm{ml} / \mathrm{L}$ & $93.50^{\mathrm{a}}$ & $95.50^{\mathrm{ab}}$ & $1.50^{\mathrm{ab}}$ & $1.57^{\mathrm{cd}}$ \\
\hline $\mathrm{EE} 50 \mathrm{ml} / \mathrm{L}$ & $86.00^{\mathrm{ab}}$ & $92.12^{\mathrm{b}}$ & $1.52^{\mathrm{ab}}$ & $1.57^{\mathrm{cd}}$ \\
\hline EE $100 \mathrm{ml} / \mathrm{L}$ & $91.62^{\mathrm{a}}$ & $95.37^{\mathrm{ab}}$ & $1.70^{\mathrm{ab}}$ & $1.92^{\mathrm{b}}$ \\
\hline SA $100 \mathrm{ppm}$ & $85.37^{\mathrm{ab}}$ & $90.12^{\mathrm{b}}$ & $1.60^{\mathrm{ab}}$ & $2.05^{\mathrm{b}}$ \\
\hline SA $200 \mathrm{ppm}$ & $94.00^{\mathrm{a}}$ & $99.37^{\mathrm{a}}$ & $1.90^{\mathrm{a}}$ & $2.87^{\mathrm{a}}$ \\
\hline Mancozeb & $85.37^{\mathrm{ab}}$ & $85.37^{\mathrm{bc}}$ & $1.55^{\mathrm{ab}}$ & $1.45^{\mathrm{cd}}$ \\
\hline Control & $80.00^{\mathrm{b}}$ & $83.62^{\mathrm{c}}$ & $1.20^{\mathrm{b}}$ & $1.32^{\mathrm{d}}$ \\
\hline \multicolumn{5}{|c|}{ Interaction $(\mathbf{C} \times \mathbf{F})$} \\
\hline \multicolumn{5}{|c|}{ Giza 716} \\
\hline $\mathrm{GE} 50 \mathrm{ml} / \mathrm{L}$ & 90.00 & 92.50 & 1.25 & 1.40 \\
\hline $\mathrm{GE} 100 \mathrm{ml} / \mathrm{L}$ & 97.75 & 101.75 & 1.45 & 1.60 \\
\hline $\mathrm{OE} 50 \mathrm{ml} / \mathrm{L}$ & 90.25 & 93.00 & 1.35 & 1.35 \\
\hline $\mathrm{OE} 100 \mathrm{ml} / \mathrm{L}$ & 99.25 & 100.75 & 1.60 & 1.65 \\
\hline EE $50 \mathrm{ml} / \mathrm{L}$ & 91.75 & 94.25 & 1.55 & 1.50 \\
\hline $\mathrm{EE} 100 \mathrm{ml} / \mathrm{L}$ & 97.50 & 97.50 & 1.75 & 2.15 \\
\hline SA $100 \mathrm{ppm}$ & 92.00 & 92.75 & 1.65 & 2.30 \\
\hline SA $200 \mathrm{ppm}$ & 100.50 & 106.50 & 2.05 & 3.25 \\
\hline Mancozeb & 92.75 & 91.75 & 1.70 & 1.45 \\
\hline Control & 87.00 & 89.75 & 1.20 & 1.40 \\
\hline \multicolumn{5}{|c|}{ Giza 40} \\
\hline $\mathrm{GE} 50 \mathrm{ml} / \mathrm{L}$ & 84.50 & 85.00 & 1.10 & 1.35 \\
\hline $\mathrm{GE} 100 \mathrm{ml} / \mathrm{L}$ & 86.50 & 89.75 & 1.65 & 1.65 \\
\hline $\mathrm{OE} 50 \mathrm{ml} / \mathrm{L}$ & 82.75 & 88.75 & 1.35 & 1.30 \\
\hline $\mathrm{OE} 100 \mathrm{ml} / \mathrm{L}$ & 87.75 & 90.25 & 1.40 & 1.50 \\
\hline EE $50 \mathrm{ml} / \mathrm{L}$ & 80.25 & 90.00 & 1.50 & 1.65 \\
\hline EE $100 \mathrm{ml} / \mathrm{L}$ & 85.75 & 93.25 & 1.65 & 1.70 \\
\hline SA $100 \mathrm{ppm}$ & 78.75 & 87.50 & 1.55 & 1.80 \\
\hline SA 200 ppm & 87.50 & 92.25 & 1.75 & 2.50 \\
\hline Mancozeb & 78.00 & 79.00 & 1.40 & 1.45 \\
\hline Control & 73.00 & 77.50 & 1.20 & 1.25 \\
\hline L.S.D $0.05(\mathrm{C})$ & 3.68 & 2.20 & NS & 0.03 \\
\hline L.S.D $0.05(\mathrm{~F})$ & 5.93 & 6.45 & 0.38 & 0.27 \\
\hline L.S.D $0.05(\mathrm{C} \times \mathrm{F})$ & $\mathrm{NS}$ & NS & $\mathrm{NS}$ & 0.38 \\
\hline
\end{tabular}

Means in the same column followed by the same letter(s) are not significant according to L.S.D at the probability of 0.05 .

In this respect, Fuglie (2000) mentioned that garlic leaf extract sprayed onto leaves of tomato, melon, maize, sorghum, coffee, tea, onions, bell pepper, soya beans and chili increased the yield of these crops. The increase in fruit yield by SA application may be due to a significant increase in vegetative growth parameters, minerals, photosynthetic pigments and some bio-constituents (EL-Yazeid, 2011). El-Saadony et al. (2017) reported that spraying pea plants with SA (100 ppm) and GE $(5 \%)$ had a positive significant effect in yield and 100-seed weight. The promoting effect of $\mathrm{OE}$ on growth and yield might be attributed to its higher own content from sulphur, amino acids, minerals, vitamins and thiamine, riboflovine, phytosterols, saponins and flavonoids, that act as antioxiants protecting plant cells from death and enhancing cell division and the biosynthesis of organic foods (Marrelli et al., 2019). 
Table 5: Effect of foliar spraying treatments on cultivars and their interaction for number of pods/plant and seed weight/plant during two successive seasons under field conditions.

\begin{tabular}{|c|c|c|c|c|}
\hline \multirow[t]{2}{*}{ Parameter } & \multicolumn{2}{|c|}{ No. pods/plant } & \multicolumn{2}{|c|}{ Seed weight/plant (g) } \\
\hline & $2017 / 2018$ & $2018 / 2019$ & $2017 / 2018$ & $2018 / 2019$ \\
\hline \multicolumn{5}{|l|}{ Factor } \\
\hline \multicolumn{5}{|c|}{ Cultivar (C) } \\
\hline Giza 716 & 9.71 & $11.97^{\mathrm{a}}$ & $23.02^{\mathrm{a}}$ & $24.48^{\mathrm{a}}$ \\
\hline Giza 40 & 9.34 & $10.41^{\mathrm{b}}$ & $19.91^{\mathrm{b}}$ & $21.59^{\mathrm{b}}$ \\
\hline \multicolumn{5}{|c|}{ Foliar spray ( F ) } \\
\hline $\mathrm{GE} 50 \mathrm{ml} / \mathrm{L}$ & $8.41^{\mathrm{d}}$ & $10.67^{\mathrm{b}}$ & $19.46^{\mathrm{bc}}$ & $21.17^{\mathrm{c}}$ \\
\hline $\mathrm{GE} 100 \mathrm{ml} / \mathrm{L}$ & $8.51^{\mathrm{d}}$ & $11.37^{\mathrm{b}}$ & $23.52^{\mathrm{a}}$ & $25.19^{\mathrm{ab}}$ \\
\hline $\mathrm{OE} 50 \mathrm{ml} / \mathrm{L}$ & $8.96^{\mathrm{cd}}$ & $10.07^{\mathrm{b}}$ & $21.07^{\mathrm{b}}$ & $22.28^{\mathrm{bc}}$ \\
\hline $\mathrm{OE} 100 \mathrm{ml} / \mathrm{L}$ & $10.53^{\mathrm{ab}}$ & $12.07^{\mathrm{b}}$ & $24.92^{\mathrm{a}}$ & $24.88^{\mathrm{ab}}$ \\
\hline EE $50 \mathrm{ml} / \mathrm{L}$ & $9.97^{\mathrm{bc}}$ & $10.50^{\mathrm{b}}$ & $19.51^{\mathrm{bc}}$ & $22.30^{\mathrm{bc}}$ \\
\hline $\mathrm{EE} 100 \mathrm{ml} / \mathrm{L}$ & $9.48^{c}$ & $11.01^{\mathrm{b}}$ & $23.81^{\mathrm{a}}$ & $24.97^{\mathrm{ab}}$ \\
\hline SA 100 ppm & $10.36^{\mathrm{b}}$ & $11.62^{\mathrm{b}}$ & $21.34^{\mathrm{b}}$ & $23.96^{\mathrm{b}}$ \\
\hline SA $200 \mathrm{ppm}$ & $11.15^{\mathrm{a}}$ & $13.82^{\mathrm{a}}$ & $24.31^{\mathrm{a}}$ & $25.91^{\mathrm{a}}$ \\
\hline Mancozeb & $9.23^{\mathrm{cd}}$ & $11.02^{\mathrm{b}}$ & $18.85^{\mathrm{c}}$ & $20.41^{\mathrm{cd}}$ \\
\hline Control & $8.65^{\mathrm{d}}$ & $9.75^{\mathrm{b}}$ & $17.83^{\mathrm{c}}$ & $19.27^{\mathrm{d}}$ \\
\hline \multicolumn{5}{|c|}{ Interaction ( $\mathbf{C} \times \mathbf{F}$ ) } \\
\hline \multicolumn{5}{|c|}{ Giza 716} \\
\hline $\mathrm{GE} 50 \mathrm{ml} / \mathrm{L}$ & 9.10 & 11.73 & 20.64 & 22.44 \\
\hline $\mathrm{GE} 100 \mathrm{ml} / \mathrm{L}$ & 8.75 & 12.50 & 25.48 & 27.02 \\
\hline $\mathrm{OE} 50 \mathrm{ml} / \mathrm{L}$ & 9.68 & 10.35 & 22.70 & 24.35 \\
\hline $\mathrm{OE} 100 \mathrm{ml} / \mathrm{L}$ & 10.88 & 12.80 & 27.07 & 26.93 \\
\hline $\mathrm{EE} 50 \mathrm{ml} / \mathrm{L}$ & 10.35 & 9.90 & 19.92 & 23.37 \\
\hline $\mathrm{EE} 100 \mathrm{ml} / \mathrm{L}$ & 9.10 & 11.63 & 26.83 & 26.01 \\
\hline SA $100 \mathrm{ppm}$ & 10.13 & 13.40 & 22.77 & 24.96 \\
\hline SA $200 \mathrm{ppm}$ & 10.83 & 15.40 & 26.30 & 27.63 \\
\hline Mancozeb & 9.55 & 12.05 & 19.81 & 21.76 \\
\hline Control & 8.75 & 10.00 & 18.76 & 20.36 \\
\hline \multicolumn{5}{|c|}{ Giza 40} \\
\hline GE $50 \mathrm{ml} / \mathrm{L}$ & 7.75 & 9.63 & 18.29 & 19.90 \\
\hline $\mathrm{GE} 100 \mathrm{ml} / \mathrm{L}$ & 8.28 & 10.25 & 21.58 & 23.38 \\
\hline $\mathrm{OE} 50 \mathrm{ml} / \mathrm{L}$ & 8.25 & 9.80 & 19.45 & 20.23 \\
\hline $\mathrm{OE} 100 \mathrm{ml} / \mathrm{L}$ & 10.19 & 11.35 & 22.79 & 22.85 \\
\hline EE $50 \mathrm{ml} / \mathrm{L}$ & 9.60 & 11.10 & 19.11 & 21.25 \\
\hline $\mathrm{EE} 100 \mathrm{ml} / \mathrm{L}$ & 9.88 & 10.40 & 20.81 & 23.94 \\
\hline SA 100 ppm & 10.60 & 9.85 & 19.93 & 22.98 \\
\hline SA 200 ppm & 11.48 & 12.25 & 22.34 & 24.19 \\
\hline Mancozeb & 8.93 & 10.00 & 17.90 & 19.08 \\
\hline Control & 8.55 & 9.50 & 16.92 & 18.20 \\
\hline L.S.D 0.05 (C) & NS & 1.01 & 1.28 & 1.70 \\
\hline L.S.D $0.05(\mathrm{~F})$ & 0.78 & 1.61 & 1.43 & 1.86 \\
\hline L.S.D $0.05(\mathrm{C} \times \mathrm{F})$ & 1.10 & NS & 2.02 & $\mathrm{NS}$ \\
\hline
\end{tabular}

Means in the same column followed by the same letter(s) are not significant according to L.S.D at the probability of 0.05 .

From the interaction, there are significant differences between cultivars and the spraying treatments in first season for 100- seed weight. The obtained data indicated that Giza 716 x SA 200 ppm had the highest 100- seed weight followed by Giza 716 x EE 100 and Giza 716 x OE 100 ml/L. In case of seed yield/fed the interaction between cultivars and spraying treatments showed significant increase compared to control treatment. In the first season, Giza 716 x SA 200 ppm had the highest value followed by Giza 716 x OE 100 and Giza 716 x GE $100 \mathrm{ml} / \mathrm{L}$. 
Table 6: Effect of foliar spraying treatments on cultivars and their interaction for 100- seed weight (g) and seed yield/fed (kg) during two successive seasons under field conditions.

\begin{tabular}{|c|c|c|c|c|}
\hline \multirow[t]{2}{*}{ Parameter } & \multicolumn{2}{|c|}{ 100- seed weight $(\mathrm{g})$} & \multicolumn{2}{|c|}{ Seed yield/fed (kg) } \\
\hline & $2017 / 2018$ & $2018 / 2019$ & $2017 / 2018$ & $2018 / 2019$ \\
\hline \multirow{2}{*}{\multicolumn{5}{|c|}{ Cultivar (C) }} \\
\hline & & & & \\
\hline Giza 716 & $74.40^{\mathrm{a}}$ & $83.61^{\mathrm{a}}$ & $1645.95^{\mathrm{a}}$ & $1732.47^{\mathrm{a}}$ \\
\hline Giza 40 & $64.93^{\mathrm{b}}$ & $66.97^{\mathrm{b}}$ & $1418.25^{\mathrm{b}}$ & $1450.29^{b}$ \\
\hline \multicolumn{5}{|c|}{ Foliar spray (F) } \\
\hline GE $50 \mathrm{ml} / \mathrm{L}$ & $67.31^{\mathrm{cd}}$ & $74.88^{\mathrm{b}}$ & $1489.32^{\mathrm{b}}$ & $1587.90^{\mathrm{b}}$ \\
\hline $\mathrm{GE} 100 \mathrm{ml} / \mathrm{L}$ & $69.06^{\mathrm{bc}}$ & $75.81^{\mathrm{ab}}$ & $1699.05^{\mathrm{a}}$ & $1722.02^{\mathrm{a}}$ \\
\hline $\mathrm{OE} 50 \mathrm{ml} / \mathrm{L}$ & $69.50^{\mathrm{bc}}$ & $71.84^{\mathrm{bc}}$ & $1504.02^{\mathrm{b}}$ & $1627.12^{\mathrm{b}}$ \\
\hline $\mathrm{OE} 100 \mathrm{ml} / \mathrm{L}$ & $74.00^{\mathrm{a}}$ & $80.05^{\mathrm{ab}}$ & $1670.87^{\mathrm{a}}$ & $1736.05^{\mathrm{a}}$ \\
\hline $\mathrm{EE} 50 \mathrm{ml} / \mathrm{L}$ & $67.87^{\mathrm{c}}$ & $75.19^{\mathrm{b}}$ & $1520.60^{\mathrm{b}}$ & $1537.90^{\mathrm{b}}$ \\
\hline EE $100 \mathrm{ml} / \mathrm{L}$ & $71.18^{\mathrm{b}}$ & $79.19^{\mathrm{ab}}$ & $1574.00^{\mathrm{b}}$ & $1596.67^{b}$ \\
\hline SA $100 \mathrm{ppm}$ & $69.87^{\mathrm{bc}}$ & $73.57^{\mathrm{bc}}$ & $1526.25^{b}$ & $1612.75^{b}$ \\
\hline SA $200 \mathrm{ppm}$ & $75.12^{\mathrm{a}}$ & $81.18^{\mathrm{a}}$ & $1723.72^{\mathrm{a}}$ & $1779.12^{\mathrm{a}}$ \\
\hline Mancozeb & $67.75^{\mathrm{c}}$ & $71.96^{\mathrm{bc}}$ & $1337.22^{\mathrm{c}}$ & $1382.35^{\mathrm{c}}$ \\
\hline Control & $65.00^{\mathrm{d}}$ & $69.21^{\mathrm{c}}$ & $1284.75^{\mathrm{c}}$ & $1331.92^{\mathrm{c}}$ \\
\hline \multicolumn{5}{|c|}{ Interaction $(\mathrm{C} \times \mathrm{F})$} \\
\hline \multicolumn{5}{|c|}{ Giza 716} \\
\hline GE $50 \mathrm{ml} / \mathrm{L}$ & 71.13 & 83.58 & 1518.85 & 1680.80 \\
\hline $\mathrm{GE} 100 \mathrm{ml} / \mathrm{L}$ & 71.63 & 84.17 & 1838.60 & 1941.15 \\
\hline $\mathrm{OE} 50 \mathrm{ml} / \mathrm{L}$ & 75.00 & 80.31 & 1638.30 & 1794.90 \\
\hline $\mathrm{OE} 100 \mathrm{ml} / \mathrm{L}$ & 76.75 & 89.92 & 1853.70 & 1935.90 \\
\hline EE $50 \mathrm{ml} / \mathrm{L}$ & 74.00 & 82.48 & 1630.85 & 1622.30 \\
\hline $\mathrm{EE} 100 \mathrm{ml} / \mathrm{L}$ & 78.25 & 89.26 & 1711.60 & 1754.25 \\
\hline SA 100 ppm & 75.25 & 81.10 & 1656.00 & 1819.45 \\
\hline SA $200 \mathrm{ppm}$ & 80.25 & 89.16 & 1928.50 & 1993.90 \\
\hline Mancozeb & 72.75 & 80.07 & 1364.55 & 1410.90 \\
\hline Control & 69.00 & 76.07 & 1318.50 & 1370.93 \\
\hline \multicolumn{5}{|c|}{ Giza 40} \\
\hline GE $50 \mathrm{ml} / \mathrm{L}$ & 63.50 & 66.20 & 1441.80 & 1495.00 \\
\hline $\mathrm{GE} 100 \mathrm{ml} / \mathrm{L}$ & 66.50 & 67.47 & 1559.50 & 1502.90 \\
\hline $\mathrm{OE} 50 \mathrm{ml} / \mathrm{L}$ & 64.00 & 63.64 & 1370.10 & 1459.35 \\
\hline $\mathrm{OE} 100 \mathrm{ml} / \mathrm{L}$ & 71.25 & 70.20 & 1488.05 & 1536.20 \\
\hline EE $50 \mathrm{ml} / \mathrm{L}$ & 61.75 & 67.91 & 1410.35 & 1453.50 \\
\hline $\mathrm{EE} 100 \mathrm{ml} / \mathrm{L}$ & 64.13 & 69.14 & 1436.35 & 1439.10 \\
\hline SA 100 ppm & 64.50 & 66.05 & 1396.50 & 1406.05 \\
\hline SA $200 \mathrm{ppm}$ & 70.00 & 73.20 & 1518.95 & 1564.35 \\
\hline Mancozeb & 62.75 & 63.85 & 1309.90 & 1353.90 \\
\hline Control & 61.00 & 62.35 & 1251.00 & 1292.60 \\
\hline L.S.D $0.05(\mathrm{C})$ & 1.98 & 3.75 & 48.63 & 73.74 \\
\hline L.S.D $0.05(\mathrm{~F})$ & 2.53 & 5.50 & 91.65 & 72.11 \\
\hline L.S.D $0.05(\mathrm{C} \times \mathrm{F})$ & 3.59 & $\mathrm{NS}$ & 129.95 & 102.24 \\
\hline
\end{tabular}

Means in the same column followed by the same letter(s) are not significant according to L.S.D at the probability of 0.05 .

\section{Physiological traits}

Effect of foliar spraying treatments on cultivars and their interaction for faba bean chlorophyll a, $b$ and $a+b$ content ( $\mathrm{mg} / \mathrm{g}$ leaves fresh weight)

Data presented in Table (7) show that Giza 716 cv. had higher contents of chlorophyll a (1.362 and 1.368), chlorophyll $\mathrm{b}$ (0.636 and 0.663) and chlorophyll $\mathrm{a}+\mathrm{b}$ (1.999 and 2.032) in both seasons, respectively. These results are in agreement with the finding exhibited by El-Shafey et al. (2019).
The results indicated that spraying treatments had significant effects in increasing faba bean leaves chlorophyll contents compared to control treatment. Plants sprayed with SA 200 ppm, GE 100 and OE $100 \mathrm{ml} / \mathrm{L}$ had the highest chlorophyll content in the first season, while in the second season, OE $100 \mathrm{had}$ the highest chlorophyll a content followed by GE $100 \mathrm{ml} / \mathrm{L}$ and SA $200 \mathrm{ppm}$. 
Table 7: Effect of foliar spraying treatments on cultivars and their interaction for leaf chlorophyll a, b and $a+b$ content $(\mathrm{mg} / \mathrm{g}$ leaves fresh weight) after $\mathbf{7 5}$ days from sowing during two successive seasons under field conditions.

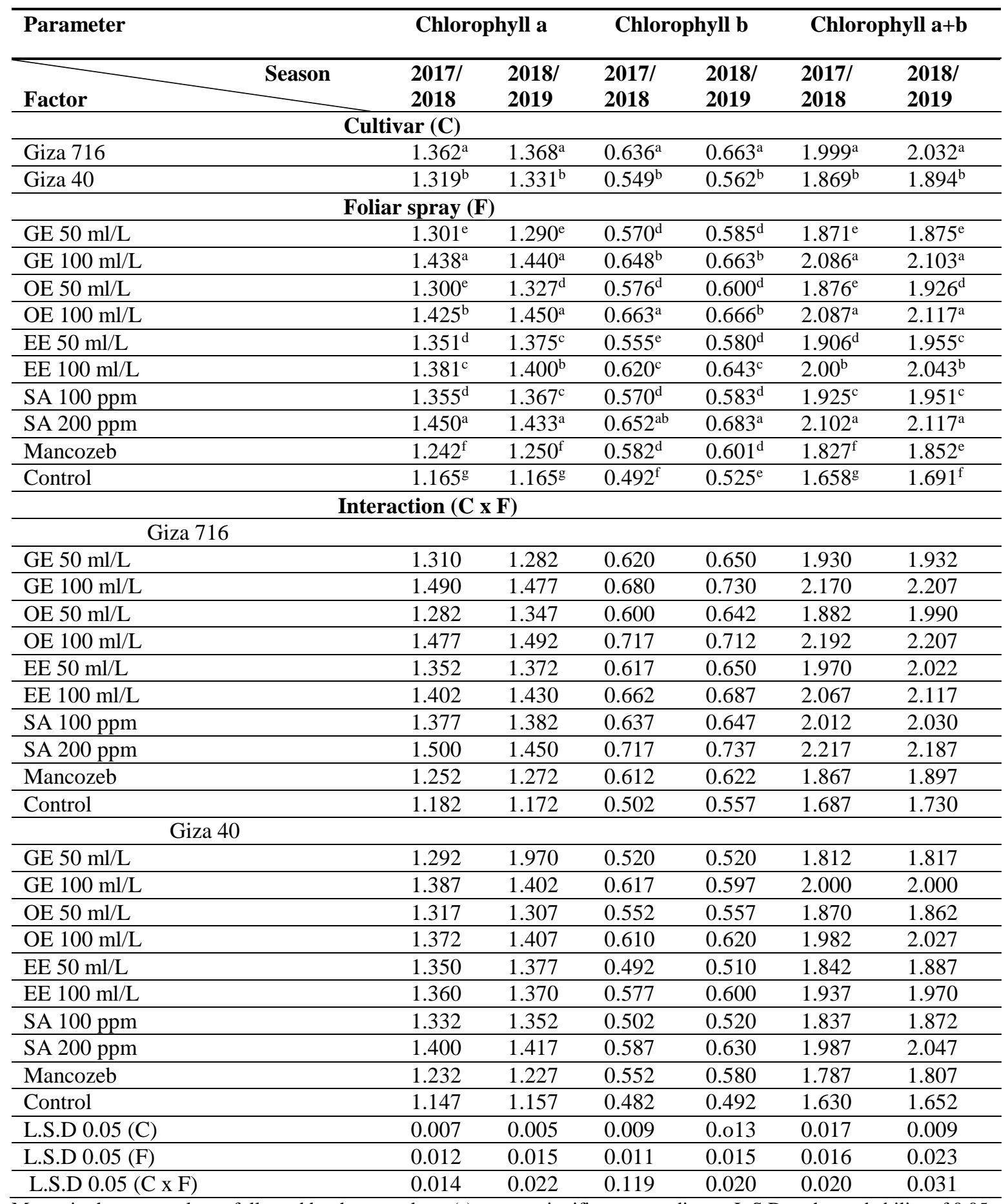

Means in the same column followed by the same letter(s) are not significant according to L.S.D at the probability of 0.05 .

In case of chlorophyll b OE $100 \mathrm{ml} / \mathrm{L}$ had the highest content followed by SA $200 \mathrm{ppm}$ and GE $100 \mathrm{ml} / \mathrm{L}$ with averages of $(0.663,0.652$ and 0.648$)$ in the first season but in the second season SA 200 ppm had the highest chlorophyll b content followed by OE 100 and GE $100 \mathrm{ml} / \mathrm{L}$. Finally SA 200 ppm had the first grade followed by OE 100 and GE 100 $\mathrm{ml} / \mathrm{L}$ for chlorophyll $\mathrm{a}+\mathrm{b}$ content in both seasons. The increase in chlorophyll content with SA confirmed the report of El-Awadi et al. (2017) for faba bean. El-Saadony et al. (2017) reported that spraying pea plants with SA (100 ppm) and GE (5\%) had a positive significant effect in photosynthetic pigments (chlorophyll a, chlorophyll 
$b$, chlorophyll $a+b)$. The positive effect of spraying SA on photosynthetic pigments may be due to their enhancing effect on the endogenous cytokinins level (Shehata et al., 2001) which stimulate growth and chloroplast differentiation.

The interaction between cultivars and foliar spray had significant effect on chlorophyll content. Giza 716 x SA 200 ppm had the highest value of chlorophyll $\mathrm{a}+\mathrm{b}$.

Effect of foliar spraying treatments on cultivars and their interaction for faba bean seed contents of total carbohydrates and total proteins $\%$ in the second season

Data illustrated in Figure (1) appear that seeds of Giza $716 \mathrm{cv}$. significantly had higher total carbohydrates and protein \% than Giza $40 \mathrm{cv}$.

Spraying treatments increased significantly total carbohydrates and protein seed contents compared to control. GE $100 \mathrm{ml} / \mathrm{L}$ treatment had the first grade of total carbohydrates \% followed by SA $200 \mathrm{ppm}$ and EE $100 \mathrm{ml} / \mathrm{L}$ treatments with averages of (53.16, 52.94 and 52.82\%), respectively. While, in case of total protein \% GE $100 \mathrm{ml} / \mathrm{L}$ and SA 200 ppm had the first grade followed by OE $100 \mathrm{ml} / \mathrm{L}$ with averages of $(24.42,24.42$ and $23.95 \%$ ), respectively. Wanas (2007) reported that faba bean seeds soaked in GE (50 and $100 \mathrm{ml} / \mathrm{L}$ ) and SA (100 and $200 \mathrm{ppm}$ ) significantly enhanced concentrations of crude protein and total carbohydrates in seeds. The same trend was obtained by Aldesuquy (2015) and El- Awadi et al. (2017) for SA. Dawood et al. (2012) reported that salicylic acid treatment enhanced biosynthesis of total carbohydrates of sunflower plants. El-Saadony et al. (2017) reported that spraying pea plants with salicylic acid at (100 ppm) and garlic extract at $(5 \%)$ had a positive significant effect in increasing carbohydrates. Mady (2014) reported that application of SA caused an increment of carbohydrates content; this might be due to the activation of the movement and translocation of nitrites in the internal plant tissues and enhances synthesis of chlorophyll to increase the photosynthesis mechanism that may lead to more carbohydrates production.

In this respect the interaction between cultivars and spraying treatments had significant increase in seed carbohydrates and protein \%. Giza 716 x OE $100 \mathrm{ml} / \mathrm{L}$ treatment had the highest content of carbohydrate followed by SA $200 \mathrm{ppm}$ and GE 100 $\mathrm{ml} / \mathrm{L}$. While, Giza 716 x GE $100 \mathrm{ml} / \mathrm{L}$ had the highest content of protein followed by SA $200 \mathrm{ppm}$ and $\mathrm{OE} 100 \mathrm{ml} / \mathrm{L}$.

Effect of foliar spraying treatments on cultivars and their interaction for peroxidase, catalase activities and total phenols content in leaves after $\mathbf{7 5}$ days from sowing in the second season.

To limit oxidative damage caused by the excess ROS, plants have a defense antioxidative systems to control the cytotoxic effects of these free radicals, which include enzymes such as superoxide dismutase (SOD), peroxidase (PO), ascorbate peroxidase (APX) and catalase (CAT) (Mittler, 2002).
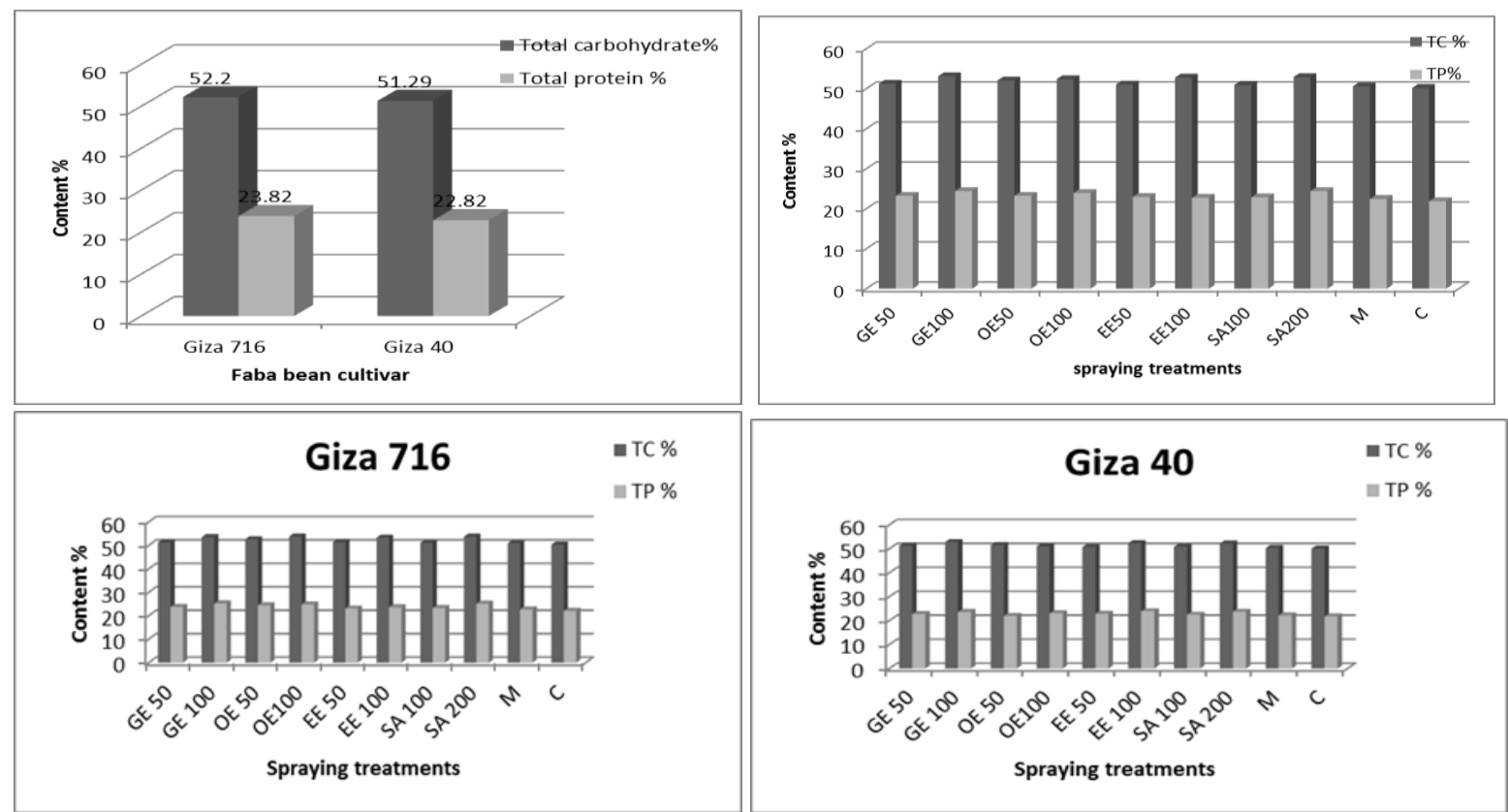

Fig. 1. Effect of foliar spraying treatments (upper right) on cultivars (upper left), and their interaction (lower row) for faba bean seed total carbohydrates content \% (TC \%) and total protein \% (TP \%) in the second season.

LSD 5\% for cultivars $=0.58($ TC \%) and $0.17($ TP \%).

LSD $5 \%$ for spraying= $0.34($ TC \% $)$ and $0.24($ TP \% $)$.

LSD 5\% for interaction $=0.48(\mathrm{TC} \%)$ and $0.34(\mathrm{TP} \%)$. 
Accumulation of phenolic compounds at the infection sites showed a correlation with the restriction of pathogen development, since such compounds are toxic substances to pathogens. The resistance may be increased by change of $\mathrm{pH}$ of plant cell cytoplasm, due to the increase in phenolic acid content, resulting in inhibition of pathogen development (Khaledi et al., 2015). In addition, phenolic compounds may impede pathogen infection by increasing the mechanical strength of the host cell wall (Usha and Jyothsna, 2010).

Data in Table (8) appear that Giza $716 \mathrm{cv}$. had higher peroxidase, catalase activities and total phenol content after 75 days from sowing in the second season than Giza 40 with averages of $(0.662,0.760$ and 0.603$)$, respectively.

Table 8: Effect of foliar spraying treatments on cultivars and their interaction for peroxidase, catalase activities, total phenols content in leaves after 75 days from sowing, chocolate spot disease severity\% (DS \%) and spot diameter using detached leaf technique in vitro during the second season.

\begin{tabular}{|c|c|c|c|c|c|}
\hline $\begin{array}{ll}\text { Factor } & \text { Parameter } \\
\end{array}$ & $\begin{array}{l}\text { Peroxidase } \\
\text { activity }\end{array}$ & $\begin{array}{l}\text { Catalase } \\
\text { activity }\end{array}$ & $\begin{array}{l}\text { Total } \\
\text { phenols }\end{array}$ & $\begin{array}{l}\text { Disease } \\
\text { severity \% }\end{array}$ & $\begin{array}{l}\text { Spot diameter } \\
(\mathbf{m m})\end{array}$ \\
\hline \multicolumn{6}{|c|}{ Cultivar $(\mathbf{C})$} \\
\hline Giza 716 & $0.662^{\mathrm{a}}$ & $0.760^{\mathrm{a}}$ & $0.603^{\mathrm{a}}$ & $28.56^{\mathrm{b}}$ & $0.49^{b}$ \\
\hline Giza 40 & $0.497^{\mathrm{b}}$ & $0.525^{\mathrm{b}}$ & $0.609^{\mathrm{b}}$ & $33.62^{\mathrm{a}}$ & $1.55^{\mathrm{a}}$ \\
\hline \multicolumn{6}{|c|}{ Foliar spray (F) } \\
\hline $\mathrm{GE} 50 \mathrm{ml} / \mathrm{L}$ & $0.582^{c}$ & $0.560^{c}$ & $0.608^{\mathrm{e}}$ & $29.91^{\mathrm{d}}$ & $1.82^{b}$ \\
\hline $\mathrm{GE} 100 \mathrm{ml} / \mathrm{L}$ & $0.649^{\mathrm{a}}$ & $0.613^{\mathrm{b}}$ & $0.787^{\mathrm{b}}$ & $25.00^{\mathrm{e}}$ & $1.12^{\mathrm{d}}$ \\
\hline $\mathrm{OE} 50 \mathrm{ml} / \mathrm{L}$ & $0.580^{\mathrm{c}}$ & $0.576^{\mathrm{c}}$ & $0.604^{\mathrm{e}}$ & $36.04^{\mathrm{b}}$ & $0.26^{\mathrm{g}}$ \\
\hline $\mathrm{OE} 100 \mathrm{ml} / \mathrm{L}$ & $0.648^{\mathrm{a}}$ & $0.599^{b}$ & $0.780^{\mathrm{b}}$ & $31.68^{c}$ & $0.20^{\mathrm{g}}$ \\
\hline EE $50 \mathrm{ml} / \mathrm{L}$ & $0.558^{\mathrm{d}}$ & $0.545^{\mathrm{d}}$ & $0.714^{\mathrm{c}}$ & $27.78^{\mathrm{e}}$ & $1.42^{\mathrm{c}}$ \\
\hline EE $100 \mathrm{ml} / \mathrm{L}$ & $0.633^{\mathrm{b}}$ & $0.615^{\mathrm{b}}$ & $0.785^{\mathrm{b}}$ & $26.39^{\mathrm{e}}$ & $0.39^{\mathrm{f}}$ \\
\hline SA 100 ppm & $0.574^{\mathrm{c}}$ & $0.565^{\mathrm{c}}$ & $0.650^{\mathrm{d}}$ & $27.78^{\mathrm{e}}$ & $0.87^{\mathrm{e}}$ \\
\hline SA $200 \mathrm{ppm}$ & $0.631^{\mathrm{b}}$ & $0.639^{\mathrm{a}}$ & $0.821^{\mathrm{a}}$ & $25.00^{\mathrm{e}}$ & $0.95^{\mathrm{e}}$ \\
\hline Mancozeb & $0.534^{\mathrm{e}}$ & $0.526^{\mathrm{e}}$ & $0.600^{\mathrm{e}}$ & $25.00^{\mathrm{e}}$ & $0.22^{\mathrm{g}}$ \\
\hline Control & $0.410^{\mathrm{f}}$ & $0.406^{\mathrm{f}}$ & $0.497^{\mathrm{f}}$ & $56.31^{\mathrm{a}}$ & $2.92^{\mathrm{a}}$ \\
\hline \multicolumn{6}{|c|}{ Interaction $(\mathrm{C} \times \mathrm{F})$} \\
\hline \multicolumn{6}{|l|}{ Giza 716} \\
\hline GE $50 \mathrm{ml} / \mathrm{L}$ & 0.658 & 0.592 & 0.711 & 27.78 & 0.21 \\
\hline $\mathrm{GE} 100 \mathrm{ml} / \mathrm{L}$ & 0.727 & 0.655 & 0.901 & 25.00 & 0.13 \\
\hline $\mathrm{OE} 50 \mathrm{ml} / \mathrm{L}$ & 0.674 & 0.610 & 0.682 & 34.80 & 0.17 \\
\hline $\mathrm{OE} 100 \mathrm{ml} / \mathrm{L}$ & 0.711 & 0.634 & 0.898 & 27.08 & 0.13 \\
\hline $\mathrm{EE} 50 \mathrm{ml} / \mathrm{L}$ & 0.618 & 0.576 & 0.763 & 26.39 & 1.10 \\
\hline EE $100 \mathrm{ml} / \mathrm{L}$ & 0.701 & 0.646 & 0.863 & 26.39 & 0.25 \\
\hline SA 100 ppm & 0.685 & 0.624 & 0.698 & 27.78 & 1.00 \\
\hline SA $200 \mathrm{ppm}$ & 0.721 & 0.682 & 0.917 & 25.00 & 0.13 \\
\hline Mancozeb & 0.639 & 0.574 & 0.625 & 25.00 & 0.13 \\
\hline Control & 0.494 & 0.440 & 0.550 & 40.36 & 1.60 \\
\hline \multicolumn{6}{|l|}{ Giza 40} \\
\hline GE $50 \mathrm{ml} / \mathrm{L}$ & 0.506 & 0.529 & 0.506 & 32.03 & 3.43 \\
\hline $\mathrm{GE} 100 \mathrm{ml} / \mathrm{L}$ & 0.573 & 0.527 & 0.674 & 25.00 & 2.10 \\
\hline $\mathrm{OE} 50 \mathrm{ml} / \mathrm{L}$ & 0.486 & 0.543 & 0.527 & 37.28 & 0.35 \\
\hline $\mathrm{OE} 100 \mathrm{ml} / \mathrm{L}$ & 0.585 & 0.564 & 0.663 & 36.28 & 0.27 \\
\hline EE $50 \mathrm{ml} / \mathrm{L}$ & 0.499 & 0.515 & 0.667 & 29.17 & 1.73 \\
\hline EE $100 \mathrm{ml} / \mathrm{L}$ & 0.565 & 0.585 & 0.709 & 26.39 & 0.53 \\
\hline SA $100 \mathrm{ppm}$ & 0.463 & 0.507 & 0.603 & 27.78 & 1.60 \\
\hline SA $200 \mathrm{ppm}$ & 0.542 & 0.596 & 0.725 & 25.00 & 0.90 \\
\hline Mancozeb & 0.431 & 0.479 & 0.575 & 25.00 & 0.31 \\
\hline Control & 0.328 & 0.370 & 0.445 & 72.26 & 4.23 \\
\hline L.S.D $0.05(\mathrm{C})$ & 0.007 & 0.006 & 0.006 & 2.49 & 0.27 \\
\hline L.S.D $0.05(\mathrm{~F})$ & 0.013 & 0.014 & 0.024 & 1.47 & 0.12 \\
\hline L.S.D $0.05(\mathrm{C} \times \mathrm{F})$ & 0.019 & 0.020 & 0.031 & 4.65 & 0.38 \\
\hline
\end{tabular}

Means in the same column followed by the same letter(s) are not significant according to L.S.D at the probability of 0.05 . 
In this respect El-Komy (2014) reported that the differences in the activities between cultivars suggested that CAT plays a major role in faba bean resistance to chocolate spot.

Spraying treatments significantly increased PO and CAT activities compared to Mancozeb and control treatments. Chickpea plants responded very quickly to $\mathrm{SA}$ at $1.5 \mathrm{mM}$ and showed higher induction of peroxidase (POD) and polyphenol oxidase (PPO) activities, besides the higher accumulation of phenols (War et al., 2011). GE 100 $\mathrm{ml} / \mathrm{L}$ treatment had the highest PO activity followed by $\mathrm{OE} 100$ and $\mathrm{EE} 100 \mathrm{ml} / \mathrm{L}$ with averages of (0.649, 0.648 and 0.633$)$, respectively. In case of CAT activity SA 200 ppm treatment had the highest value followed by EE 100 and GE $100 \mathrm{ml} / \mathrm{L}$ with averages of $(0.639,0.615$ and 0.613$)$, respectively. Gholamnezhad et al. (2016) showed that the maximum activity of CAT was observed after $24 \mathrm{~h}$ of Mycosphaerella graminicola infection in Zagros (tolerant wheat cultivar) when sprayed with $2 \mathrm{mM}$ of SA. In this respect, spraying treatments significantly increased total phenols compared to control treatment only. SA $200 \mathrm{ppm}$ treatment had the highest value followed by GE 100 and OE 100 $\mathrm{ml} / \mathrm{L}$ with averages of $(0.821,0.787$ and 0.780$)$, respectively. Mbazia et al. (2016) found that foliar spray of faba bean with SA increased total phenols.

On the other hand, the interaction between cultivars and spraying treatments showed significant differences in PO, CAT and total phenols. It can be noticed that the response of Giza 716 to spraying treatments was more than that of Giza 40. In case of PO activity, Giza 716 x GE 100 had the first grade followed by SA 200 ppm, OE 100 and EE $100 \mathrm{ml} / \mathrm{L}$. While, the activity of CAT was the highest by SA $200 \mathrm{ppm}, \mathrm{GE}$ 100, EE 100 and OE $100 \mathrm{ml} / \mathrm{L}$. SA $200 \mathrm{ppm}$ treatment had the highest value of total phenols followed by GE 100, OE 100 and EE 100 $\mathrm{ml} / \mathrm{L}$.

\section{Chocolate spot disease severity}

Effect of cultivars, foliar spraying treatments and their interaction on chocolate spot disease severity \% (DS) and spot diameter using detached leaf technique in vitro in the second season

Data presented in Table (8) show that sprayed detached leaves of faba bean Giza $716 \mathrm{cv}$. (taken after $24 \mathrm{~h}$ from plants previously sprayed with the tested botanical extracts under field conditions) with spores suspension of Botrytis fabae $\left(3 \times 10^{6}\right)$ significantly had the least disease severity \% (28.56 $\%)$ compared to Giza 40 (33.62\%). The same trend was cleared using spore suspension droplet using leaflet technique where spore diameter in case of the leaflets of Giza 716 was $(0.49 \mathrm{~mm})$ but it was $(1.55$ $\mathrm{mm}$ ) on the leaflets of Giza 40. These results may be due to the effect of the defensive enzymes had the plants. In this respect El-Komy (2014) reported that peroxidase and catalase enzymes activities increased in leaves of resistant cultivars of faba bean compared to susceptible one.

The results indicated that spraying treatments with GE, OE, EE, SA and Mancozeb decreased DS $\%$ and spot diameter (mm) compared to control treatment. Şimşek and Duman (2017) mentioned that 1, 8-cineole (eucalyptol) was the major component in the leaves of Eucalyptus globulus and had an antimicrobial effect against some microorganisms. GE $100 \mathrm{ml} / \mathrm{L}$, SA $200 \mathrm{ppm}$ and Mancozeb had the best effect in reducing DS \% with an average of $25 \%$ for each. In case of spot diameter (mm) OE $100 \mathrm{ml} / \mathrm{L}$ treatment had the least value followed by Mancozeb, OE $50 \mathrm{ml} / \mathrm{L}$ with averages of $(0.20,0.22$ and $0.26 \mathrm{~mm})$, respectively. There were significant differences between spraying botanical extracts treatments and control.

The interaction effect data indicated that spraying Giza 716 and Giza 40 cultivars with GE $100 \mathrm{ml} / \mathrm{L}$, SA $200 \mathrm{ppm}$ and Mancozeb had the least values for disease severity with an average of $25 \%$ for each. Giza 716 sprayed with GE 100, OE 100 $\mathrm{ml} / \mathrm{L}$, SA $200 \mathrm{ppm}$ and Mancozeb had the least values for spot diameter with an average of (0.13 $\mathrm{mm}$ ) for each. While, when Giza 40 sprayed with GE $100 \mathrm{ml} / \mathrm{L}$, Mancozeb, GE 50 and EE $100 \mathrm{ml} / \mathrm{L}$ had the averages of $(0.27,0.31,0.35$ and $0.53 \mathrm{~mm})$, respectively.

Effect of foliar spraying treatments on cultivars and their interaction for chocolate spot disease severity under field coditions

Data presented in Table (9) and Figure (2) show the response of faba bean cultivars and the effect of spraying treatments under study and their interaction on disease severity (DS \%). Generally, disease severity increased with increasing periods from 75 to 105 days. Giza 716 had the lower DS \% after 75, 90 and 105 days from sowing in both seasons than Giza 40 with general averages of (1.79 and $1.93 \%)$ in first and second seasons, respectively (Fig. 2-A). In this respect Yitayih and Azmeraw (2018) mentioned that the differences between faba bean cultivars for chocolate spot disease incidence and severity may be due to the genetic variation among cultivars to the infection.

Spraying treatments significantly decreased DS $\%$ compared to control treatment in both seasons. SA 200 ppm had the lowest DS \% values in the first season followed by $\mathrm{OE} 100 \mathrm{ml} / \mathrm{L}$ with general averages of (1.66 and $1.77 \%)$, respectively. In the second season OE $100 \mathrm{ml} / \mathrm{L}$ had the lowest DS \% values followed by SA $200 \mathrm{ppm}$ with general averages of (1.85 and $1.90 \%)$, respectively (Fig. 2B). 
Table 9: Effect of foliar spraying treatments on cultivars and their interaction for chocolate spot disease severity \% caused by Botrytis fabae after 75, 90 and 105 days from sowing during two successive seasons under field conditions.

\begin{tabular}{|c|c|c|c|c|c|c|}
\hline Parameter & \multicolumn{4}{|c|}{ Chocolate spot disease severity \% } & \multirow{3}{*}{$2017 / 2018$} & \multirow{3}{*}{ 2018/2019 } \\
\hline Season & $2017 / 2018$ & 2018/2019 & 2017/2018 & 2018/2019 & & \\
\hline Factor -2 & & & & & & \\
\hline & \multicolumn{2}{|c|}{ (75 day) } & \multicolumn{2}{|c|}{ (90 day) } & \multicolumn{2}{|c|}{ (105 day) } \\
\hline \multicolumn{7}{|c|}{ Cultivar (C) } \\
\hline Giza 716 & 1.01 & $1.13^{\mathrm{b}}$ & $1.48^{\mathrm{b}}$ & 1.97 & 2.88 & $2.68^{\mathrm{b}}$ \\
\hline Giza 40 & 1.07 & $1.34^{\mathrm{a}}$ & $1.86^{\mathrm{a}}$ & 2.50 & 3.56 & $4.14^{\mathrm{a}}$ \\
\hline \multicolumn{7}{|c|}{ Foliar spray (F) } \\
\hline $\mathrm{GE} 50 \mathrm{ml} / \mathrm{L}$ & $1.24^{\mathrm{ab}}$ & $2.02^{\mathrm{a}}$ & $2.02^{\mathrm{a}}$ & $2.23^{\mathrm{bc}}$ & $3.27^{\mathrm{b}}$ & $3.85^{\mathrm{ab}}$ \\
\hline $\mathrm{GE} 100 \mathrm{ml} / \mathrm{L}$ & $1.13^{\mathrm{b}}$ & $1.84^{\mathrm{ab}}$ & $1.84^{\mathrm{ab}}$ & $2.28^{\mathrm{bc}}$ & $3.18^{\mathrm{b}}$ & $3.30^{\mathrm{bc}}$ \\
\hline $\mathrm{OE} 50 \mathrm{ml} / \mathrm{L}$ & $1.05^{\mathrm{bc}}$ & $1.72^{\mathrm{ab}}$ & $1.72^{\mathrm{ab}}$ & $2.20^{\mathrm{bc}}$ & $3.43^{\mathrm{b}}$ & $3.27^{\mathrm{bc}}$ \\
\hline $\mathrm{OE} 100 \mathrm{ml} / \mathrm{L}$ & $0.85^{\mathrm{cd}}$ & $1.44^{\mathrm{ab}}$ & $1.44^{\mathrm{ab}}$ & $1.83^{\mathrm{c}}$ & $3.01^{\mathrm{b}}$ & $2.77^{\mathrm{c}}$ \\
\hline EE $50 \mathrm{ml} / \mathrm{L}$ & $1.14^{\mathrm{b}}$ & $1.71^{\mathrm{ab}}$ & $1.71^{\mathrm{ab}}$ & $2.10^{\mathrm{bc}}$ & $3.15^{\mathrm{b}}$ & $3.53^{\mathrm{b}}$ \\
\hline $\mathrm{EE} 100 \mathrm{ml} / \mathrm{L}$ & $1.00^{\mathrm{bc}}$ & $1.60^{\mathrm{ab}}$ & $1.60^{\mathrm{ab}}$ & $1.95^{\mathrm{bc}}$ & $3.10^{\mathrm{b}}$ & $3.47^{\mathrm{b}}$ \\
\hline SA $100 \mathrm{ppm}$ & $0.93^{\mathrm{c}}$ & $1.60^{\mathrm{ab}}$ & $1.60^{\mathrm{ab}}$ & $2.01^{\mathrm{bc}}$ & $3.20^{\mathrm{b}}$ & $3.51^{\mathrm{b}}$ \\
\hline SA $200 \mathrm{ppm}$ & $0.75^{\mathrm{d}}$ & $1.28^{\mathrm{b}}$ & $1.28^{\mathrm{b}}$ & $1.87^{\mathrm{bc}}$ & $2.95^{\mathrm{b}}$ & $2.93^{\mathrm{bc}}$ \\
\hline Mancozeb & $0.95^{\mathrm{c}}$ & $1.45^{\mathrm{ab}}$ & $1.45^{\mathrm{ab}}$ & $2.45^{\mathrm{b}}$ & $3.11^{\mathrm{b}}$ & $3.22^{\mathrm{bc}}$ \\
\hline Control & $1.39^{\mathrm{a}}$ & $2.01^{\mathrm{a}}$ & $2.01^{\mathrm{a}}$ & $3.43^{\mathrm{a}}$ & $3.83^{\mathrm{a}}$ & $4.23^{\mathrm{a}}$ \\
\hline \multicolumn{7}{|c|}{ Interaction $(\mathbf{C} \times \mathbf{F})$} \\
\hline \multicolumn{7}{|c|}{ Giza 716} \\
\hline $\mathrm{GE} 50 \mathrm{ml} / \mathrm{L}$ & 1.21 & 1.92 & 1.92 & 2.18 & 2.92 & 2.93 \\
\hline $\mathrm{GE} 100 \mathrm{ml} / \mathrm{L}$ & 1.06 & 1.53 & 1.53 & 1.95 & 2.72 & 2.90 \\
\hline $\mathrm{OE} 50 \mathrm{ml} / \mathrm{L}$ & 1.14 & 1.55 & 1.55 & 2.03 & 3.00 & 2.80 \\
\hline $\mathrm{OE} 100 \mathrm{ml} / \mathrm{L}$ & 0.84 & 1.28 & 1.28 & 1.53 & 2.71 & 2.05 \\
\hline $\mathrm{EE} 50 \mathrm{ml} / \mathrm{L}$ & 1.10 & 1.56 & 1.56 & 2.00 & 2.82 & 2.93 \\
\hline EE $100 \mathrm{ml} / \mathrm{L}$ & 1.02 & 1.39 & 1.39 & 1.68 & 2.98 & 2.70 \\
\hline SA $100 \mathrm{ppm}$ & 0.89 & 1.35 & 1.35 & 1.70 & 2.85 & 2.58 \\
\hline SA $200 \mathrm{ppm}$ & 0.73 & 1.20 & 1.20 & 1.60 & 2.69 & 2.30 \\
\hline Mancozeb & 0.97 & 1.25 & 1.25 & 2.03 & 2.89 & 2.58 \\
\hline Control & 1.19 & 1.75 & 1.75 & 3.08 & 3.25 & 3.05 \\
\hline \multicolumn{7}{|l|}{ Giza 40} \\
\hline $\mathrm{GE} 50 \mathrm{ml} / \mathrm{L}$ & 1.27 & 2.13 & 2.13 & 2.30 & 3.62 & 4.78 \\
\hline GE $100 \mathrm{ml} / \mathrm{L}$ & 1.19 & 2.16 & 2.16 & 2.63 & 3.64 & 3.70 \\
\hline $\mathrm{OE} 50 \mathrm{ml} / \mathrm{L}$ & 0.96 & 1.89 & 1.89 & 2.38 & 3.86 & 3.75 \\
\hline $\mathrm{OE} 100 \mathrm{ml} / \mathrm{L}$ & 0.86 & 1.60 & 1.60 & 2.15 & 3.31 & 3.50 \\
\hline $\mathrm{EE} 50 \mathrm{ml} / \mathrm{L}$ & 1.18 & 1.86 & 1.86 & 2.20 & 3.49 & 4.15 \\
\hline EE $100 \mathrm{ml} / \mathrm{L}$ & 0.98 & 1.80 & 1.80 & 2.20 & 3.22 & 4.25 \\
\hline SA 100 ppm & 0.96 & 1.84 & 1.84 & 2.33 & 3.56 & 4.45 \\
\hline SA 200 ppm & 0.78 & 1.37 & 1.37 & 2.15 & 3.21 & 3.58 \\
\hline Mancozeb & 0.94 & 1.65 & 1.65 & 2.88 & 3.33 & 3.88 \\
\hline Control & 1.59 & 2.27 & 2.27 & 3.80 & 4.40 & 5.43 \\
\hline L.S.D $0.05(\mathrm{C})$ & $\mathrm{NS}$ & 0.26 & 0.26 & $\mathrm{NS}$ & $\mathrm{NS}$ & 0.49 \\
\hline L.S.D $0.05(\mathrm{~F})$ & 0.17 & 0.36 & 0.36 & 0.37 & 0.31 & 0.61 \\
\hline L.S.D $0.05(\mathrm{C} \times \mathrm{F})$ & NS & $\mathrm{NS}$ & NS & NS & $\mathrm{NS}$ & $\mathrm{NS}$ \\
\hline
\end{tabular}

Means in the same column followed by the same letter(s) are not significant according to L.S.D at the probability of 0.05 .

These results are in agreement to the findings of Hassan et al. (2006) who revealed that SA caused remarkable induced resistance effects against chocolate spot disease of faba bean when compared with control. Aldesuquy et al. (2014) reported that the application of SA could be effective in enhancing the uptake of some inorganic nutrients which play a role in decreasing the incidence of chocolate spot disease. Thus, improvement in plant nutrition can enhance plant development and increased plant resistance against the effect of disease.

Many reports showed that some natural plant products increased oxidative enzymes in plants that can play an important role in the resistance (Senthilraja et al., 2013 and Raj et al., 2016). In case of the botanical extracts, leaves of Eucalyptus globulus were reported to have high amount of 
oxalic acid (Alabi et al., 2005) which is among chemicals known to act as defense inducers in plants (Mousavi and Raftos, 2012).

The inhibitive action of garlic bulb crude extract on fungal growth has been attributed to the existence of allicin, as the major anti-bacterial, antifungal and anti-viral component (Miron et al., 2000). Presence of flavonoids from the onion (Allium cepa) extract was reported by Palomar et al. (2004) these flavonoids inhibit the growth of microorganisms. Irkin and Korukluoglu (2007) proved that garlic, onion, and leek extracts inhibited the multiplication of Aspergillus niger.
In case of the interaction between faba bean cultivars and the spraying treatments data in Table (10) and Fig. (2-C and D) show that DS \% decreased with the two sprayed cultivars, while the difference between cultivars was not significant.

Figure (3) appear the efficacy of spraying some botanical extracts, salicylic acid and Mancozeb in reducing chocolate spot disease severity. Data appear that in the first season, SA $200 \mathrm{ppm}$ had the highest efficacy followed by OE $100 \mathrm{ml} / \mathrm{L}$ with averages of (31.12 and $26.56 \%$ ), respectively. In the second season, OE $100 \mathrm{ml} / \mathrm{L}$ had the highest efficacy followed by SA 200 ppm with averages of (43.25 and $41.72 \%$ ), respectively.
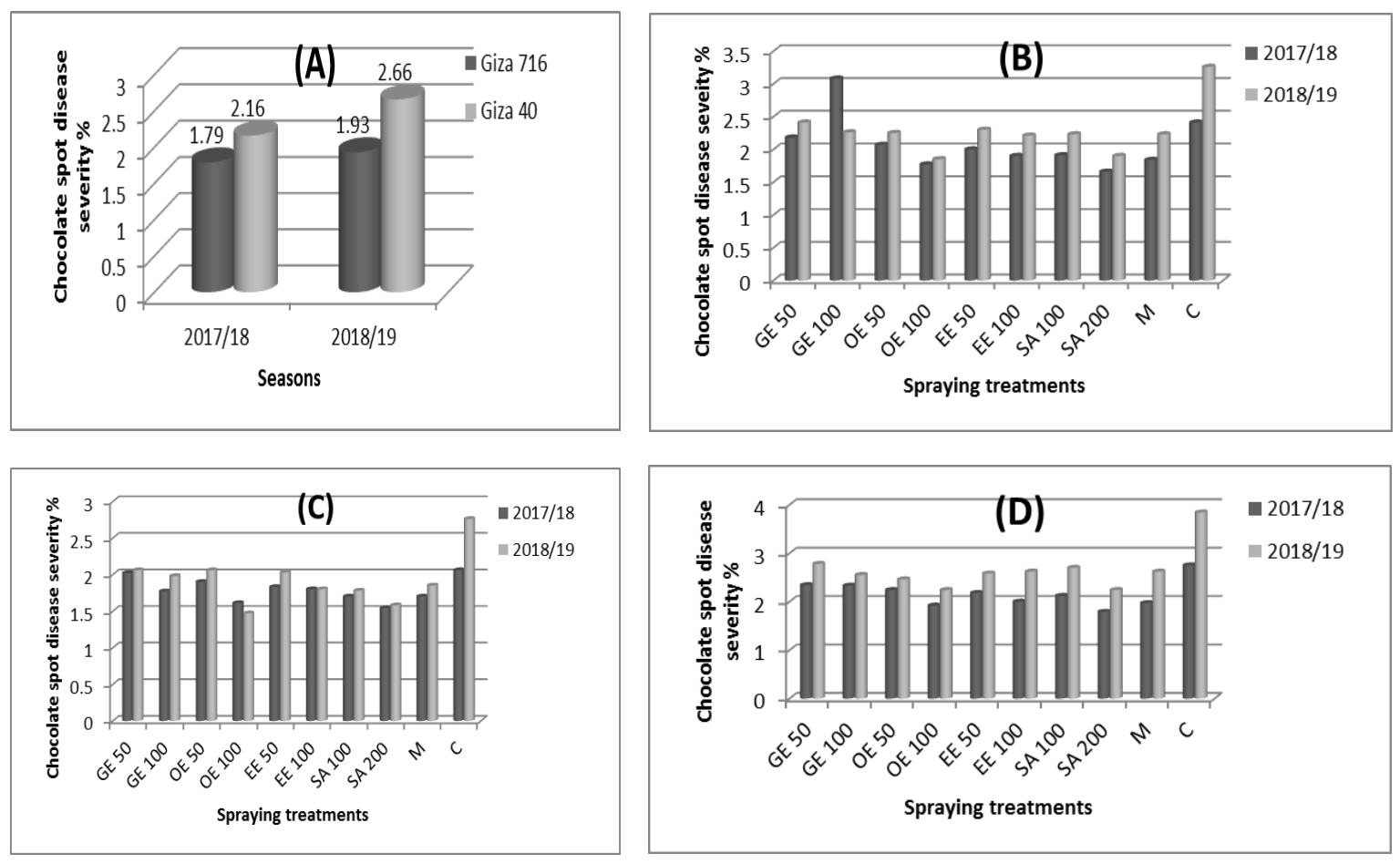

Fig. 2: Response of faba bean cultivars (A), spraying treatments (B) and their interaction Giza 716 (C), Giza 40 (D) on chocolate spot disease severity \% under field conditions (averages of two seasons).

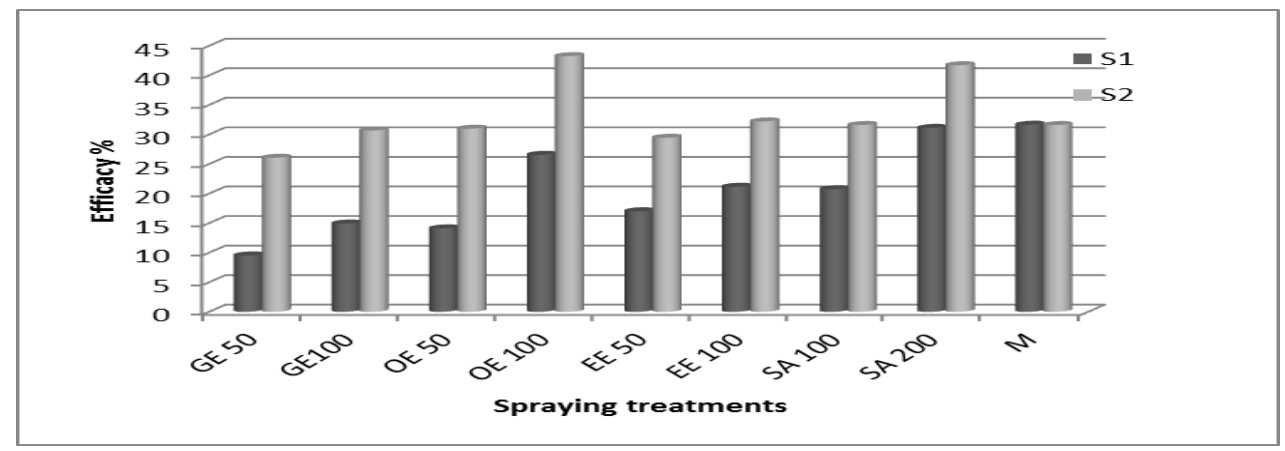

Fig. 3: Efficacy of spraying garlic cloves (GE), onion bulb (OE), eucalyptus leaves (EE) extracts (50 and $100 \mathrm{ml} / \mathrm{L})$, salicylic acid (100 and $200 \mathrm{ppm})$ and Mancozeb in reducing faba bean chocolate spot disease severity \% during two successive seasons 2017/2018 (S1) and 2018/2019 (S2) under field conditions. 


\section{CONCLUSION}

Based in the previous results and discussion, under field conditions it can be concluded that spraying the aqueous extracts of garlic cloves, onion bulb and eucalyptus leaves (50 and $100 \mathrm{ml} / \mathrm{L}$ ) in addition to salicylic acid (100 and $200 \mathrm{ppm}$ ) improved most characteristics of faba bean vegetative growth, yield and some chemical components. SA $200 \mathrm{ppm}$ increased chlorophyll a, $\mathrm{b}$ and $\mathrm{a}+\mathrm{b}$ also it had the highest catalase activity, total phenols and seed protein \%. SA $200 \mathrm{ppm}$ and OE $100 \mathrm{ml} / \mathrm{L}$ treatments had the lowest chocolate spot disease severity. Using detached leaf technique under laboratory conditions, the chocolate spot diameter and its severity were well decreased after spraying the previous plant extracts or salicylic acid. Therefore, these green chemicals can be used as naturally and environmentally safe fungitoxicant agents to control the chocolate spot disease of faba bean.

\section{REFERRNCES}

Alabi, D. A., M. Z. Onibudol and N. A. Amusa (2005). Chemicals and Nutritional Compositions of four Botanicals with Fungitoxic Properties. World J. Agric., Sci., 1: 84-88.

Aldesuquy, H. S. (2015). Shikimic acid and salicylic acid induced protection on growth vigor, seed yield and biochemical aspects of yielded seeds of Vicia faba plants infected by Botrytis fabae. J. Plant Pathol. Microb., 6 (9): 304-311.

Aldesuquy, H. S., Z. A. Baka, M. A. Abass, Nahla T. Alazab (2014). Faba bean can adapt to chocolate spot disease by pretreatment with shikimic and salicylic acids through osmotic adjustment, solutes allocation and leaf turgidity. J. Stress Physiol. Biochem., 10 (1): 230-243.

Al-Mayahi, Manal Z. and M. H. Fayadh (2015). The effects of garlic extract, its application methods and their interaction on growth and yield of potato, Solanum tuberosum (L.) Cv. Latonia. Adv. Agric. Botanics- Inter.J. Bioflux Society, 7 (1): 59-69.

Amadioha A.C. (2000): Controlling rice blast in vitro and in vivo with extracts of Azadirachta indica. Crop Protection, 19: 287-290.

Amako, A., K. Chen and K. Asada (1994). Separate assays specific for ascorbate peroxidase and gauiacol peroxidase and for the chloroplastic and cytosolic isoenxymes of ascorbate peroxidase in plants. Plant Cell Physiol., 35: 497-504.
AOAC (1988). Official Methods of Analysis $21^{\text {st }}$ Ed., Association of Official agricultural Chemists, Washington, DC, USA.

Asad Ullah, R. Kh., I. Kh. Zafar Ullah, S. Khan, A. B. Ali and N. A. Khan (2019). Foliar application of plant extracts and salicylic acid affects the growth and yield of tomato. Inter. J. Biosci., 14 (1): 417-426.

Azzini, E., A. Durazzo, , M. S. Foddai,, O. Temperini, E. Venneria, S. Valentini and G. Maiani (2014). Phytochemicals content in Italian garlic bulb (Allium sativum L.) varieties. J. Food Res., 3, 26-32.

Baka, Z. A. M., H. S. Aldesuquy, M. A. Abass and N. T. Alazab (2012). Effect of shikimic and salicylic acids on the ultrastructure of chloroplasts of Vicia faba infected by Botrytis fabae. J. Environ. Sci., 41: 37-54.

Baysal, Ö., Y. Z. Gürsoy, H. Örnek and A. Duru (2005). Induction of oxidants in tomato leaves treated with DL- $\beta$-amino butyric acid (BABA) and infected with Clavibacter michiganensis ssp. michiganensis. Eur. J. Plant Pathol., 112 (4): 361- 369.

Bernier, C. C., S. B. Hanounik, M. M. Hussein and H. A. Mohamed (1984). Rating scale for faba bean diseases in Nile Vally. ICARDA Information Bulletin No. 3 p. 37.

Bernier, C. C., S. B. Hanounik, M. M. Hussein and H. A. Mohamed (1993). Field manual of common bean diseases in the Nile Valley. ICARDA Information Bulletin No. 3 p. 40.

Bouhassan, A., M. Sadiki, and B. Tivoli (2004). Evaluation of a collection of faba bean (Vicia faba L.) genotypes originating from the Maghreb for resistance to chocolate spot (Botrytis fabae) by assessment in the field and laboratory. Euphytica, 135: 55-62.

Cakmak, I. and W. J. Horst (1991). Effect of aluminum on lipid peroxidation, superoxide dismutase, catalase and peroxidase activities in root tip of soybean (Glysin max L.). J. Plant Physiol., 83: 463-468.

Carnago, D. F., E. C. Amor and W. L. Rivera (2011) Antifungal activity of onion (Allium cepa L.) bulbs extract against Fusarium oxysporum and Colletotrichum sp. The Philippine Agricultural Scientist 94: 78-82.

Dahab, Abeer A., H. N. Nady and Hemat S. Abd ElSalam (2018). The potential of some plants extract as bio-stimulants for enhancing growth and biochemical constituents of banana plantlets. Middle East J. Agric. Res., 7 (3): 904914. 
Dawood, Mona G., Mervat S. Sadak and M. Hozayen (2012). Physiological role of salicylic acid in improving performance, yield and some biochemical aspects of sunflower plant grown under newly reclaimed sandy soil. Aust. J. Basic and Appl. Sci., 6 (4): 82-89.

Derckel, J. P., F. Baillieul, S. Manteau, J. Audran, B. Haye, B. Lambert and L. Legendre (1999). Differential induction of grapevine defenses by two strains of Botrytis cinerea. Phytopatholology, 89: 197-203.

Dubois, M., K. A. Gilles, J. R. Hamilton and F. Smith (1956). Colorimetric method for determination of sugar and related substance. Annal. Chem., 28: 350-356.

EI-Awadi, M. E., M. G. Dawood, Y. R. Abdel-Baky and K. G. EI-Rokiek (2017). Investigations of growth promoting activity of some phenolic acids. Agric. Engineering International: CIGR J. 1, Special issue: 53-60.

El-Banoby, F. E., M. A. Abd-AllA., I. H. Tolba, A. A. Morsy, Nadia, G. El-Gamal- and M. S. A. Khalil (2013). Biological control of chocolate spot disease of faba bean using some bioagents under field conditions. J. Appl. Sci. Res., 9 (6): 4021-4029.

El-Hendawy, S., W. Shaban and J. I. Sakagami (2010). Does treating faba bean seeds with chemical inducers simultaneously increase chocolate spot disease resistance and yield under field conditions? Turk. J. Agric. For., 34: 475-485.

El-Komy, M. H. (2014). Comparative analysis of defense responses in chocolate spot-resistant and -susceptible faba bean (Vicia faba) cultivars following infection by the necrotrophic fungus Botrytis fabae. Plant Pathol. J., 30 (4): 355-366.

El-Saadony, F. M., Dalia A. S. Nawar and H.G. Zyada (2017). Effect of foliar application with salicylic acid, garlic extract and proline on growth, yield and leaf anatomy of pea (Pisum sativum L.) grown under drought stress. Mid. East J. Appl. Sci., 7 (3): 633-650.

El-Sayed, Sahar, A. (2017). Efficiency of some antioxidants, biocontrol agents and fungicides in induction of faba bean resistance to chocolate spot disease. SF J. Mycology, 1(1): 10-13.

El-Shafey, Amina, I., F. E. Waly, A. M. El-Garhy and M. M. H. Rahhal (2019). Effect of foliar spraying of some chelated microelements on growth, yield and chocolate spot disease severity of faba bean. Menoufia J. Plant Prod. 4, 527-550.
El-Tayeb, M. A. (2005). Response of barley grains to the interactive effect of salinity and salicylic acid. Plant Growth Regul., 45: 215-224.

El-Yazeid, A. (2011). Effect of foliar application of salicylic acid and chelated zinc on growth and productivity of sweet pepper (Capsicum annum L.) under autumn planting. Res. J. Agric. Biol. Sci., 7 (6): 423-433.

Fuglie, L. J. (2000). New uses of moringa studied in Nicaragua: ECHO"s Technical Network Sitenetworking global hunger solution ECHO (Conference), Nicaragua. Gaborone. Botswana.

Gholamnezhad, J., F. Sanjarian, E. M. Goltapeh, N. Safaie and K. Razavi (2016). Effect of salicylic acid on enzyme activity in wheat in immediate early time after infection with Mycosphaerella graminicola. Scientia Agriculturae Bohemica, 47 (1): 1-8

Gill, S. S. and N. Tuteja (2010). Reactive oxygen species and antioxidant machinery in abiotic stress tolerance in crop plants. Plant Physiol. Biochem., 48: 909-930.

Gomes, K. A. and A. A. Gomes (1984). Statistical Procedures for Agricultural Research. $2^{\text {nd }}$ ed., Wiley, New York.

Haggag, W. M., A. L. Kansoh and A. M. Aly (2006). Proteases from Talaromyces flavus and Trichoderma harzianum: Purification, characterization and antifungal activity against brown spot disease on faba bean. Plant Pathol. Bull., 15: 231-239.

Hanafy, M. S., F. M. Saadawy, M. N. Milad and M. Ali (2012). Effect of some natural extracts on growth and chemical constituents of Schefflera arboricola plants. J. Hort. Sci. \& Ornamen. Plants, 4 (1): 26-33.

Hassan, M. E. M., S. S. Abd El-Rahman, I. H. ElAbbasi and M. S. Mikhail (2006). Inducing resistance against faba bean chocolate spot disease. Egypt. J. Phytopathol., 34: 69-79.

Hunt, R. (1990). Basic Growth Analysis: Plant Growth Analysis for Beginners. Unwin Hyman Ltd., London, 55-72.

Ibrahim, A., H. Abdel-Razzak, M. Wahb-Allah, M. Alenazi, A. Alsadon and Y. H. Dewir (2019). Improvement in growth, yield, and fruit quality of three red sweet pepper cultivars by foliar application of humic and salicylic acids. HortTechnology, 29 (2): 170-178.

ICARDA (1986). Screening techniques for disease resistance in faba bean. ICARDA, Aleppo, Syria. 59 p.

Irkin, R. and M. Korukluoglu (2007) Control of Aspergillus niger with garlic, onion, and leek extract. Afr. J. Biotechnol. 6: 384-387. 
Jayakannan, M., J. Bose, O. Babourina, Z. Rengel, and S. Shabala (2015). Salicylic acid in plant salinity stress signaling and tolerance. Plant Growth Regul. 76: 25-40.

Kagale S., T. Marimuthu, B. Thayumanavan, R. Nandakumar and R. Samiyappan (2004). Antimicrobial activity and induction of systemic resistance in rice by leaf extract of Datura metel against Rhizoctonia solani and Xanthomonas oryzae pv. oryzae. Physiol. Mol. Plant Pathol., 65: 91-100.

Khaledi, N., P. Taheri and S. Tarighi (2015). Antifungal activity of various essential oils against Rhizoctonia solani and Macrophomina phaseolina as major bean pathogens. J. Appl. Microbiol., 118 (3): 704-717.

Mady, M. A. (2014). Inducing cold tolerability in squash (Cucurbita pepo L.) plant by using salicylic acid and chelated calcium application. Inter. J. Agric. Sci. Res., 4 (4): 9-24.

Marrelli. M., V. Amodeo, G. Statti and F. Confort (2019). Biological properties and bioactive components of Allium cepa L.: Focus on potential benefits in the treatment of obesity and related comorbidities. Molecules, 24, 119; doi:10.3390/molecules24010119

Mbazia, A., Noura, O. Ben Youssef and M. Kharrat (2016). Effect of some chemical inducers on chocolate spot disease of faba bean in Tunisia. J. Crop Prot., 5 (4): 541-552.

Metzner, H., H. Rau and H. Senger (1965). Studies on Synchronization of Some Pigment-deficient Chlorella Mutants. Planta, 66: 186-194. (Translated)

Miron, T., A. Rabinikov, D. Mirelman, M. Wilchek and L. Weiner (2000). The mode of action of allicin: Its ready permeability through phospholipid membranes may contribute to its biological activity. Biochinica et Biophysica Acta., 1463: 20-30.

Mittler, R. (2002). Oxidative stress, antioxidants and stress tolerance. Trends Plant Sci., 7: 405-410.

Mousavi, S. M. and D. Raftos (2012). In vitro antifungal activity of a new combination of essential oils against some filamentous fungi. Middle-East J. Sci. Res., 11: 156-161.

Murray, M. T., J. Pizzorno and M. Murray (2012). Allium sativum in: Natural Medicine. Kenmore, WA, USA: Churchill Livingstone, pp. 1941.

Nassib, A. M., Sh. A. Khalil and A. H. A. Hussein (1991). Faba bean production and consumption in Egypt. Options Mediterr., 10: 127-131.
Noreen, S. and M. Ashraf (2008). Alleviation of adverse effects of salt stress on sunflower (Helianthus annuus L.) by exogenous application of salicylic acid: growth and photosynthesis. Pak. J. Bot., 40(4): 1657-1663.

Ozyigit I. I. (2008). Phenolic changes during in vitro organogenesis of cotton (Gossypium hirsutum L.) shoot tips. Afr. J. Biotechnol., 7: 11451150 .

Palomar, M. K., E. O. Landerito, A. P. Molato, D. C. Cayanong and V. G. Palermo (2004). Antifungal activity of six botanicals against root crop disease. Ann. Trop. Res., 26: 77-95.

Pattnaik, M. M, M. Kar and R. K. Sahu (2012). Bioefficacy of some plant extracts on growth parameters and control of diseases in Lycopersicum esculentum. Asian J. Pl. Sci. Res., 2: 129-142.

Purwitasari, W. (2012). Pengaruh perasan bawang merah (Allium ascalonicum L.) terhadap pertumbuhan akarstek pucuk krisan (Chrysanthemum sp). Undergraduate thesis, FMIPA Undip Available on http://eprints.undip.ac.id/29654/ access on 19 February, 2014.

Raj, T. S., D. Anandeeswari, H. Suji and A. A. Joice (2016). Role of defense enzymes activity in rice as induced by idm formulations against sheath blight caused by Rhizoctonia solani. IJAPSA 2: 106-116.

Rewal, H. S. and J. S. Jhooty (1985). Differential response of wheat varieties to systemic fungicides applied to Ustilago tritici (Pres.). Rostr. Indian J. Agric. Sci., 55: 548-549.

Sales, M. D., H. B. Costa, P. M. Fernandes, J. A. Ventura and D. D. Meira (2016). Antifungal activity of plant extracts with potential to control plant pathogens in pineapple. Asian Pac. J. Trop. Dis., 6: 26-31.

Senthilraja, G. T., J. Anand, T. Kennedy, T. Raguchander and R. Samiyappan (2013). Plant growth promoting rhizobacteria (PGPR) and entomopathogenic fungus bioformulation enhance the expression of defense enzymes and pathogenesis-related proteins in groundnut plants against leaf miner insect and collar rot pathogen. Physiol. Mol. Plant Pathol., 82: 1019.

Shaaban, M. M., A. M. Abd EL-Aal, F. F. Ahmed (2011). Insight into the effect of salicylic acid on apple trees growing under sandy saline soil. Res. J. Agric. Biol. Sci., 7 (2): 150-156. 
Shang, A., Sh. Cao, X. Xu, R. Gan, G. Tang, H. Corke, V. Mavumengwana and H. Li (2019). Bioactive compounds and biological functions of garlic (Allium sativum L.). Foods, 8, 246; doi:10.3390/foods8070246.

Shehata, S. A. M., S. I. Ibrahim and A. M. Zaghlool (2001). Physiological response of flag leaf and ears of maize plant induced by foliar application of kinetin (Kin) and salicylic acid (SA). Annals Agric. Sci. Ain Shams Univ. Cairo, 46 (2): 435-449.

Şimşek, M. and R. Duman (2017). Investigation of effect of 1,8- cineole on antimicrobial activity of chlorhexidine gluconate. Pharmacognosy Res. 9(3): 234-237.

Singleton, V. L. and J. A. Rossi (1965). Colorimetry of total phenolics with phosphomolybdicphosphotungstic acid reagents. Am. J. Enol. Viticult., 16: 144-158.

Taffa, E. T., C. F. Gurmessa and S. S. W. Mariam (2013). In vivo assay for antagonistic potential of fungal isolates against faba bean (Vicia faba L.) chocolate spot (Botrytis fabae Sard.). Jordan J. Biol. Sci., 6 (3): 183-189.

Thakker, J. N., S. Patel and P. C. Dhandhukia (2013). Induction of defense-related enzymes in banana plants: Effect of live and dead pathogenic strain of Fusarium oxysporum f. sp. cubense, ISRN Biotech. 6 pages. doi:10.5402/2013/601303.
Tola, A. T., M. C. Egigu and B. H. Egdu (2016). Bio-efficacy of crude leaf extracts of Eucalyptus globulus against In vitro and In vivo growth of chocolate spot (Botrytis fabae Sard.) of faba bean (Vicia faba L.). Plant, 4 (5): 37-44.

Torres, A. M., R. B. Oman, C. M. Avila, Z. Satovic, D. Rubiales, J. C. Sillero, J. I. Cubero and M. T. Moreno (2004). Faba bean breeding for resistance against biotic stresses, towards application of marker technology, Euphytica, 147: 67-80.

Usha R. P. and Y. Jyothsna (2010). Biochemical and enzymatic changes in rice as a mechanism of defense. Acta Physiol. Plant., 32: 695-701.

Wanas, A. L. (2007). Response of faba bean (Vicia faba L.) plants to seed-treating with garlic extract, salicylic acid and paclobutrazol. J. Agric. Sci., Mansoura Univ., 32 (2): 971-990.

War, A. R., M. G. Paulraj, M. Y. War and S. Ignacimuthu (2011). Role of salicylic acid in induction of plant defense system in chickpea (Cicer arietinum L.). Plant Sig. Behav. 6 (11): 1787-1792.

Yitayih, G. and Y. Azmeraw (2018). Evaluation of faba bean varieties against chocolate spot (Botrytis fabae Sard.) disease at Farta, South Gondar, Ethiopia. J. Crop Sci. Biotech., 21 (1): 35-41.

Youssef, M. M. A., Wafaa M. A. El-Nagdi and Asmahan M. S. Lashein (2016). Comparative study on the effect of garlic clove and acetyl salicylic acid aqueous extracts with emphasis on inducing resistance against root knot nematode, Meloidogyne incognita on sugar beet. Inter. J. Pharm Tech Res., 9 (10): 1-7.

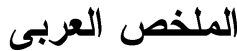

\section{تاثير رش نباتات الفول البلدى ببعض المستخلصات النباتيه وحمض الساليسيلك على النمو والمحصول وشدة اصابته بمرض التبقع الشيكولاتى}

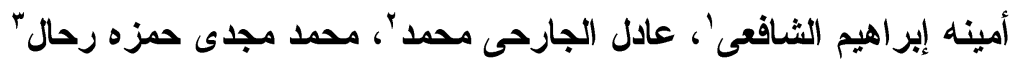

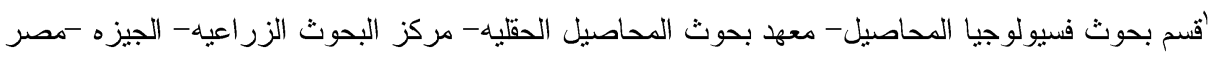

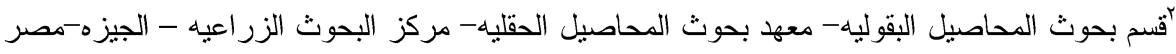

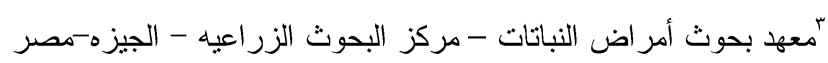

\footnotetext{
تم در اسة مدى إستجابة صنفى الفول البلدى جيزه T T T، جيزه • ـ للرش ببعض المستخلصات النباتيه بالإضافه لحمض الساليسيلك على تحسين بعض صفات النمو والمحصول و المكونات الكيميائية وعلاقة ذلك بشدة الإصابه بالتبقع الثيكو لاتى الذى يسببه فطر بوترايتس فابى. تم إستخدام مستخلصات فصوص الثوم، البصل، أوراق الكافور
} 


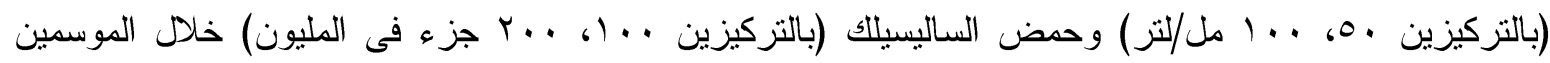

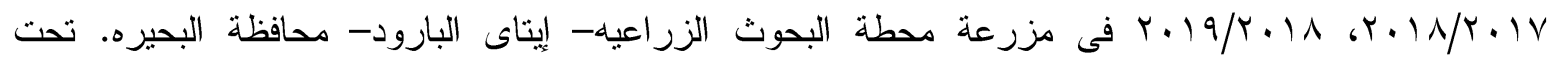
الظروف الحقليه وجد أن الصنف جيزه VIT الأعلى فى قيم القياسات الخضرية والمحصوليه المختبره فى كلا

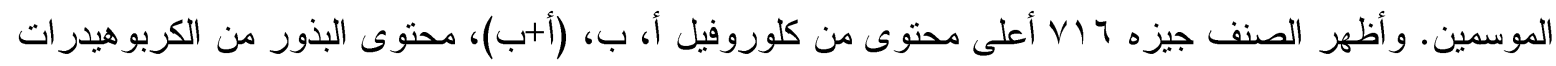

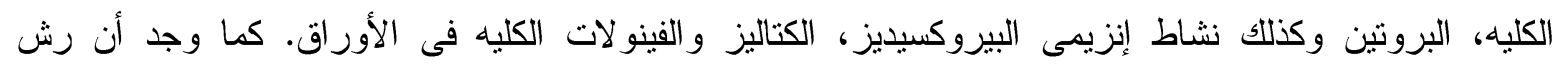
مستخلصات فصوص الثوم، البصل، أوراق الكافور، حمض الساليسيلك لها تأثير جيد فى زيادة نمو ومحصول الفول

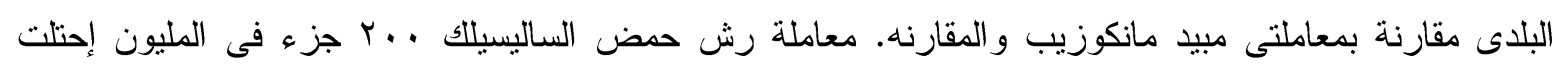

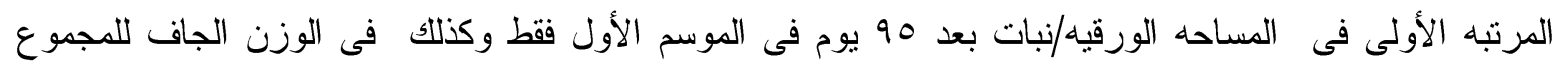

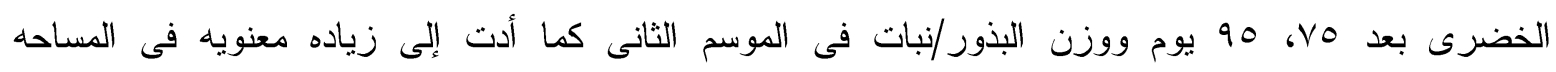

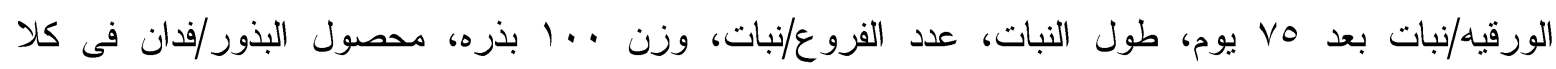
الموسمين. إحتلت هذه المعامله المرتبه الأولى وأدت إلى زياده معنويه فى محتوى أوراق الفول البلدى من كلوروفيل

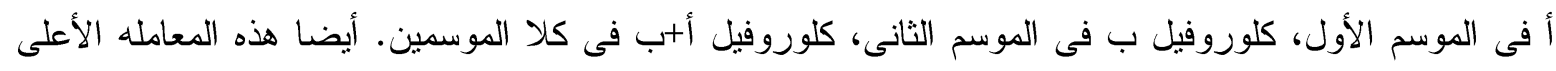

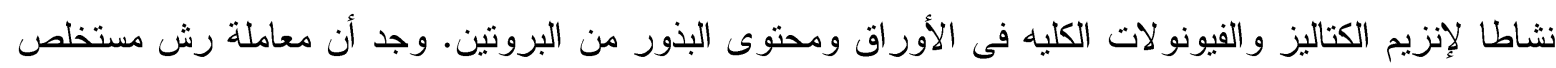

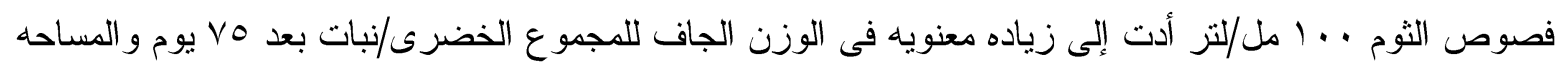

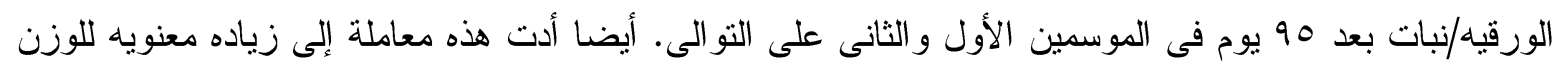

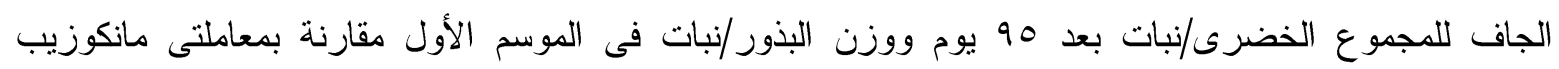

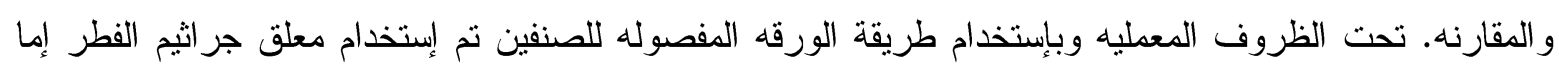

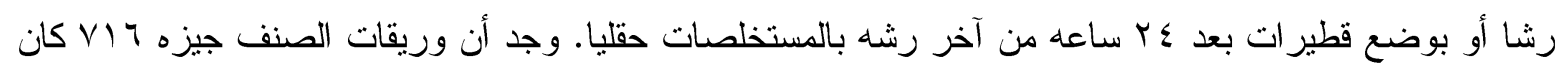

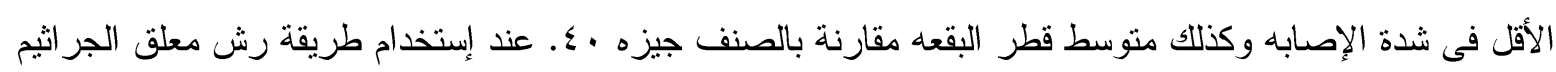

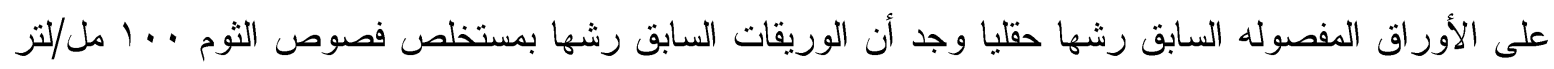

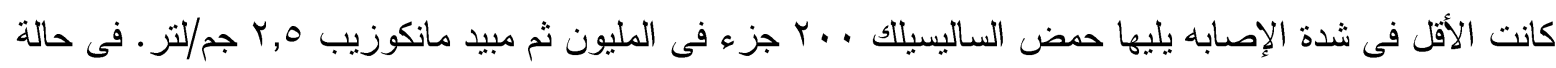

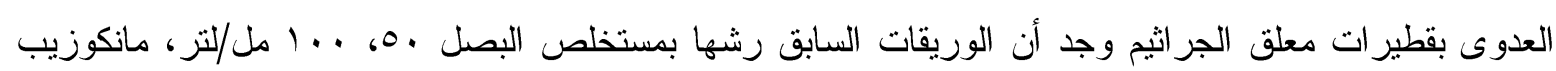

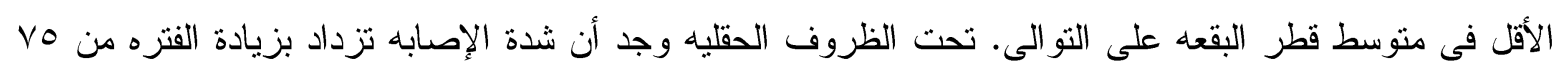

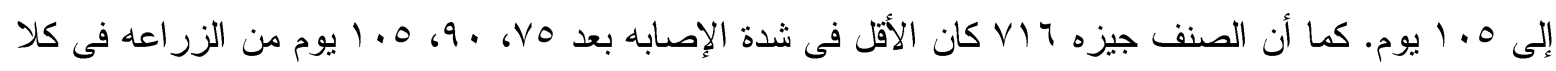

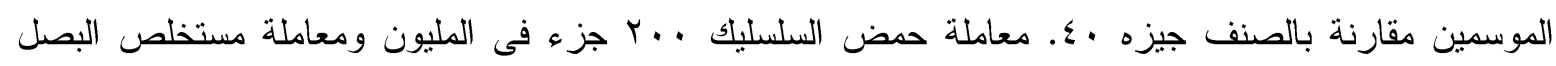

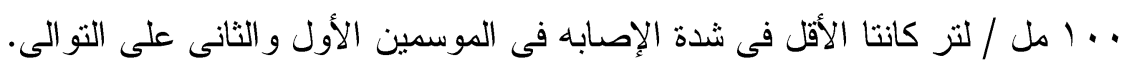

